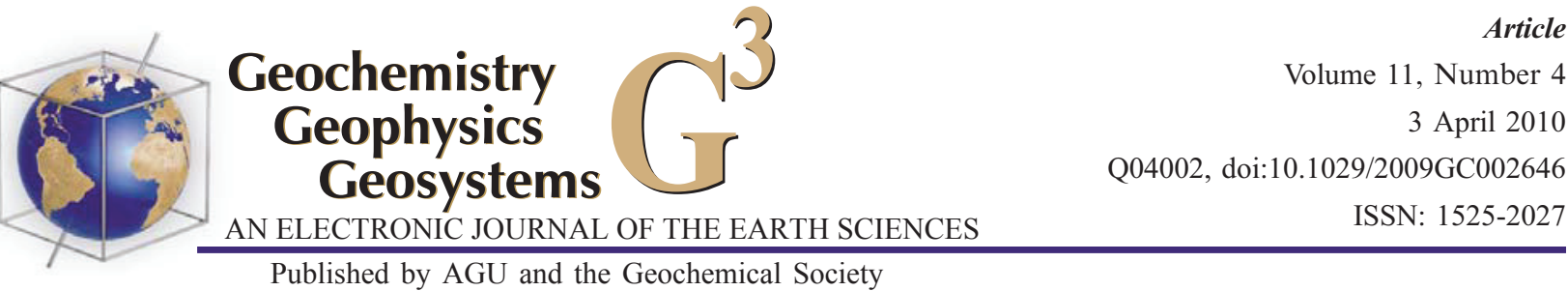

Published by AGU and the Geochemical Society

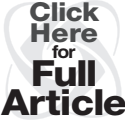

\title{
Strain localization along the Atlantis Bank oceanic detachment fault system, Southwest Indian Ridge
}

\author{
Elena A. Miranda \\ Department of Geological Sciences, California State University, 18111 Nordhoff Street, Northridge,California 91330- \\ 8266, USA (elena.miranda@csun.edu)

\section{Barbara E. John} \\ Department of Geology and Geophysics, University of Wyoming, 1000 East University Avenue, Department 3006, \\ Laramie, Wyoming 82071, USA
}

[1] Microstructural observations and mineral thermometry from in situ samples collected from the Atlantis Bank oceanic core complex (SW Indian Ridge) indicate that detachment faulting was initiated under hypersolidus conditions in the ductile regime and continued through subgreenschist temperatures through the ductile, semibrittle, and brittle regimes as strain localized along the exposed, now subhorizontal fault surface. Ductile, semibrittle, and brittle fabrics are developed within dominantly gabbroic rocks. Footwall rocks exhibit crystal plastic fabrics distributed over a structural thickness up to $400 \mathrm{~m}$ below the denuded fault surface exposed at the seafloor, whereas semibrittle and brittle fabrics are concentrated in the 80 and $30 \mathrm{~m}$ immediately below the principal slip surface of the detachment fault, respectively. Sample fabrics suggest that strain localization was achieved by dynamic recrystallization of plagioclase at temperatures between $910^{\circ} \mathrm{C}$ and $650^{\circ} \mathrm{C}$, by amphibole-accommodated dissolution-precipitation creep at temperatures $\sim 750^{\circ} \mathrm{C}-450^{\circ} \mathrm{C}$, by chlorite-accommodated reaction softening at temperatures $\sim 450^{\circ} \mathrm{C}-300^{\circ} \mathrm{C}$, and by brittle fracturing and cataclasis at temperatures $<300^{\circ} \mathrm{C}$.

Components: 16,883 words, 20 figures, 7 tables.

Keywords: oceanic core complex; strain localization; Southwest Indian Ridge; thermometry; microstructures.

Index Terms: 8030 Structural Geology: Microstructures; 8031 Structural Geology: Rheology: crust and lithosphere (8159); 3035 Marine Geology and Geophysics: Midocean ridge processes.

Received 26 May 2009; Revised 24 November 2009; Accepted 11 December 2009; Published 3 April 2010.

Miranda, E. A., and B. E. John (2010), Strain localization along the Atlantis Bank oceanic detachment fault system, Southwest Indian Ridge, Geochem. Geophys. Geosyst., 11, Q04002, doi:10.1029/2009GC002646.

\section{Introduction}

[2] Slow and ultraslow spreading mid-ocean ridges accommodate plate separation by both magmatic and tectonic processes [Karson, 1990; Smith and Cann, 1993; Tucholke and Lin, 1994; Blackman et al., 1998], where tectonic spreading is accommodated by high-angle normal faults and low-angle detachment fault systems associated with oceanic core complex formation [Karson and Dick, 1983; Karson, 1990; Dick et al., 1991a; Mutter and Karson, 1992; Tucholke and Lin, 1994; Blackman et al., 1998]. Detachment faults are identified in both on- and off-axis locations based on their distinctive dome-shaped and corrugated fault surfaces that cap the underlying oceanic core complex 
[Cann et al., 1997; Blackman et al., 1998; Tucholke et al., 1998; Karson, 1999; Ranero and Reston, 1999; Tucholke et al., 2001; MacLeod et al., 2002; Smith et al., 2006], and may make up to $60 \%$ of the seafloor locally [Smith et al., 2008]. Oceanic core complexes are thought to form at or near the ridge axis, where footwall rocks are denuded by detachment faults that dip toward the axial valley [Cann et al., 1997; Tucholke et al., 1998; Ranero and Reston, 1999; Blackman et al., 2001; MacLeod et al., 2002; deMartin et al., 2007]. Corrugated fault surfaces are commonly exposed for $\sim 15-30 \mathrm{~km}$, and extend up to $\sim 125 \mathrm{~km}$ parallel to the spreading direction, suggesting that active detachment faulting can persist for a few to several million years [Tucholke et al., 1998; Ohara et al., 2001; Escartin et al., 2003; Ildefonse et al., 2007; Harigane et al., 2008]. The recovery of variable proportions of oceanic crust and upper mantle rocks from these exposed fault surfaces has led to the development of several models for oceanic core complex formation that invoke a limited to substantial role of magma supply in the process of strain localization, as summarized by Escartin et al. [2003] and Ildefonse et al. [2007].

[3] Few oceanic core complexes have been sampled comprehensively via seafloor sampling and deep drilling efforts, but these unique samples provide the best opportunities to understand the process of strain localization and core complex development [Dick et al., 2000; Blackman et al., 2002; MacLeod et al., 2002; Escartin et al., 2003; Schroeder and John, 2004; Blackman et al., 2006; Boschi et al., 2006; Karson et al., 2006; Kelemen et al., 2007]. In the Atlantic, the eastern Kane $\left(23^{\circ} \mathrm{N}\right)$ region was sampled by ODP Holes 669, 670, and 920-924, Atlantis Massif core complex at $30^{\circ} \mathrm{N}$ was penetrated by Integrated Ocean Drilling Program (IODP) Holes U 1309B and U1309D, and the $15^{\circ} 45^{\prime} \mathrm{N}$ core complex was sampled by Ocean Drilling Program (ODP) Holes 1275B and 1275D [Karson and Lawrence, 1997a, 1997b; Blackman et al., 2006; Kelemen et al., 2007]. Core recovered from drill holes near the Kane fracture zone were all collected from the same spreading segment of the ridge; the cores from the ridgetransform intersection massif comprise gabbroic rocks with crystal plastic, semibrittle and brittle deformation fabrics, and the cores collected $\sim 15$ $\mathrm{km}$ south of the massif exhibit crystal plastically deformed ultramafic rocks [Shipboard Scientific Party, 1988; Cannat et al., 1997; Ceuleneer and Cannat, 1997; Karson and Lawrence, 1997a, 1997b]. Submersible and seafloor studies from the eastern Kane region reveal upper and lower crust rocks in the vicinity of the intersection massif, and upper crust volcanic rocks and ultramafic rocks $\sim 15 \mathrm{~km}$ south of the massif exhibiting primarily brittle deformation at greenschist grade temperatures [Karson and Dick, 1983; Karson et al., 1987; Mevel et al., 1991]. The cores from Atlantis Massif and the $15^{\circ} 45^{\prime} \mathrm{N}$ core complexes comprise primitive gabbroic and rare ultramafic rocks, and demonstrate that extensive high-strain granulite and amphibolite grade crystal plastic deformation is lacking, and that fracturing and cataclasis are rare and restricted to narrow zones in the upper 10s of meters of each hole [Shipboard Scientific Party, 2004; Blackman et al., 2006; Kelemen et al., 2007]. The rock types and deformation fabrics observed in these cores contrast with samples collected by submersible, dredging and seafloor coring. These seafloor studies indicate that the corrugated surfaces of the massifs and the footwall rocks immediately beneath it $(<70 \mathrm{~cm})$ are dominated by both semibrittle fault schists and brittle fault rocks derived from both ultramafic and mafic rocks. Structurally deeper footwall rocks exhibit fabrics indicative of high-strain, hightemperature crystal plastic deformation, and lowertemperature semibrittle and brittle deformation [Cannat et al., 1997; Blackman et al., 2002; MacLeod et al., 2002; Escartin et al., 2003; Schroeder and John, 2004; Boschi et al., 2006; Karson et al., 2006]. Together these submersible and drilling studies of the Kane, Atlantis Massif and $15^{\circ} 45^{\prime}$ core complexes suggest that strain localization processes involving both mafic and ultramafic rocks may vary laterally over short $(1-10 \mathrm{~km})$ distances, and underscore the importance of combined drilling and submersible/surface sampling in addressing the evolution of oceanic lithosphere.

[4] The Atlantis Bank oceanic core complex (Southwest Indian Ridge) exhibits extensive hypersolidus and high-temperature crystal plastic fabric development, overprinted by localized brittle fabric development within dominantly gabbroic rocks in both drill core (ODP Holes 735B and 1105A) and submersible samples [Shipboard Scientific Party, 1989; Cannat et al., 1991; Dick et al., 1991b; Shipboard Scientific Party, 1999a, 1999b; Arai et al., 2000; Dick et al., 2000; Kinoshita et al., 2001; Matsumoto et al., 2002; Miranda, 2006; Mehl and Hirth, 2008]. The hypersolidus fabrics and extensive crystal plastic deformation documented in the shear zones of ODP Hole 735B demonstrates that core complex development began during crystalli- 
zation of gabbroic rocks, and continued long after crystallization was complete. The minor percentage of ultramafic rocks and associated serpentinite recovered from the footwall rocks of Atlantis Bank suggests that strain localization processes leading to the development of a discrete detachment fault may differ from those core complexes exhibiting more heterogeneous footwall rock types. Atlantis Bank is therefore an ideal location to investigate the processes of strain localization that lead to development of a core complex associated with extensive crystal plastic fabric development within a dominantly gabbroic section. In this study, we use in situ submersible samples to investigate fabric development associated with strain localization along the Atlantis Bank detachment fault system, and compare these results with earlier studies from the ODP Hole 735B drill core.

\section{Study Location}

[5] The Atlantis Bank core complex is located $\sim 80-110 \mathrm{~km}$ south of the present-day Southwest Indian Ridge. It is a $\sim 300 \mathrm{~km}^{2}$ core complex that formed between 10 and $13 \mathrm{Ma}$ near the center of the ridge segment between the Atlantis II Transform and the nontransform discontinuity at $57^{\circ} 40^{\prime} \mathrm{E}$ (Figure 1) [Dick et al., 1991b; Stakes et al., 1991; Matsumoto et al., 2002; Natland and Dick, 2002; Hosford et al., 2003; Schwartz et al., 2005; Baines et al., 2007; Baines et al., 2008]. Bathymetric mapping across Atlantis Bank shows preservation of a dome-shaped surface dissected by moderately dipping $\left(30-50^{\circ}\right)$ transform- and ridgeparallel normal faults (Figure 2) [Dick et al., 1991b; Arai et al., 2000; Kinoshita et al., 2001; Matsumoto et al., 2002; Baines et al., 2003]. Due to normal slip along these faults, the morphology of this core complex differs from younger core complexes recognized along the Mid-Atlantic Ridge. These later faults make Atlantis Bank an ideal location for studying strain localization associated with detachment faulting as they expose structurally deep portions of the footwall normally inaccessible on younger core complexes.

[6] The footwall to the detachment fault at Atlantis Bank was first sampled in 1987 with the initial drilling of ODP Hole 735B to $\sim 500 \mathrm{mbsf}$; the Hole was later deepened to 1508 mbsf in 1997 [Shipboard Scientific Party, 1999b]. The 1508 m of core from Hole 735B is almost entirely composed of gabbroic rocks, with minor diabase and troctolite (Figure 3$)$. The bulk of the core (77\%) comprises undeformed rocks with little to no crystal plastic or brittle fabric development [Dick et al., 2000]. Strain is localized in the remaining intervals of the core within ductile shear zones and brittle fault zones, with well-developed crystal plastic and brittle fabrics, the thickest and most significant such zone is located in the upper $100 \mathrm{~m}$ of the Hole [Cannat et al., 1991; Stakes et al., 1991; Shipboard Scientific Party, 1999c].

[7] Submersible samples used in this study were sampled from broadly distributed exposures of the detachment surface at the seafloor and the footwall directly below, and likely correspond to the shear zone between 0 and $100 \mathrm{mbsf}$ in 735B. We present microstructural observations from these samples representative of the granulite, amphibolite, greenschist and subgreenschist grade fabrics observed in the main shear zone $(0-100 \mathrm{mbsf})$ associated with detachment faulting and discuss lateral variations associated with the detachment fault system to compare with earlier studies [Cannat et al., 1991].

\section{Methods}

\subsection{Sample Acquisition}

[8] To confirm the lateral extent and variability of processes associated with strain localization and development of the detachment fault system, manned and unmanned submersibles (Shinkai 6500 and Kaiko, respectively) were used to sample the detachment surface and its footwall and probable hanging wall in a total of 21 dives during three research cruises: the JAMSTEC/WHOI 20012002 ABCDE cruise, the JAMSTEC/WHOI Mode '98 cruise, and the JAMSTEC/WHOI MODE 2000 cruise (Figure 2) [Arai et al., 2000; Kinoshita et al., 2001; Matsumoto et al., 2002]. The widely distributed submersible samples provide the basis for a comprehensive study of the mechanisms of strain localization that led to development of the Atlantis Bank oceanic detachment fault system.

[9] Ninety-eight in situ samples from the ABCDE cruise, the Mode '98 cruise, and MODE 2000 cruise were used in this study. Accurate sample locations were determined using the Long Base Line and the Super Short Base Line navigational systems, with vertical sample spacing between 50 $\mathrm{m}$ and $200 \mathrm{~m}$. Samples were categorized as "from outcrop" if they were broken off of the outcrop with the robotic arms of the submersible. Samples that were dislocated from the contiguous outcrop by joints, but that were otherwise in place were 


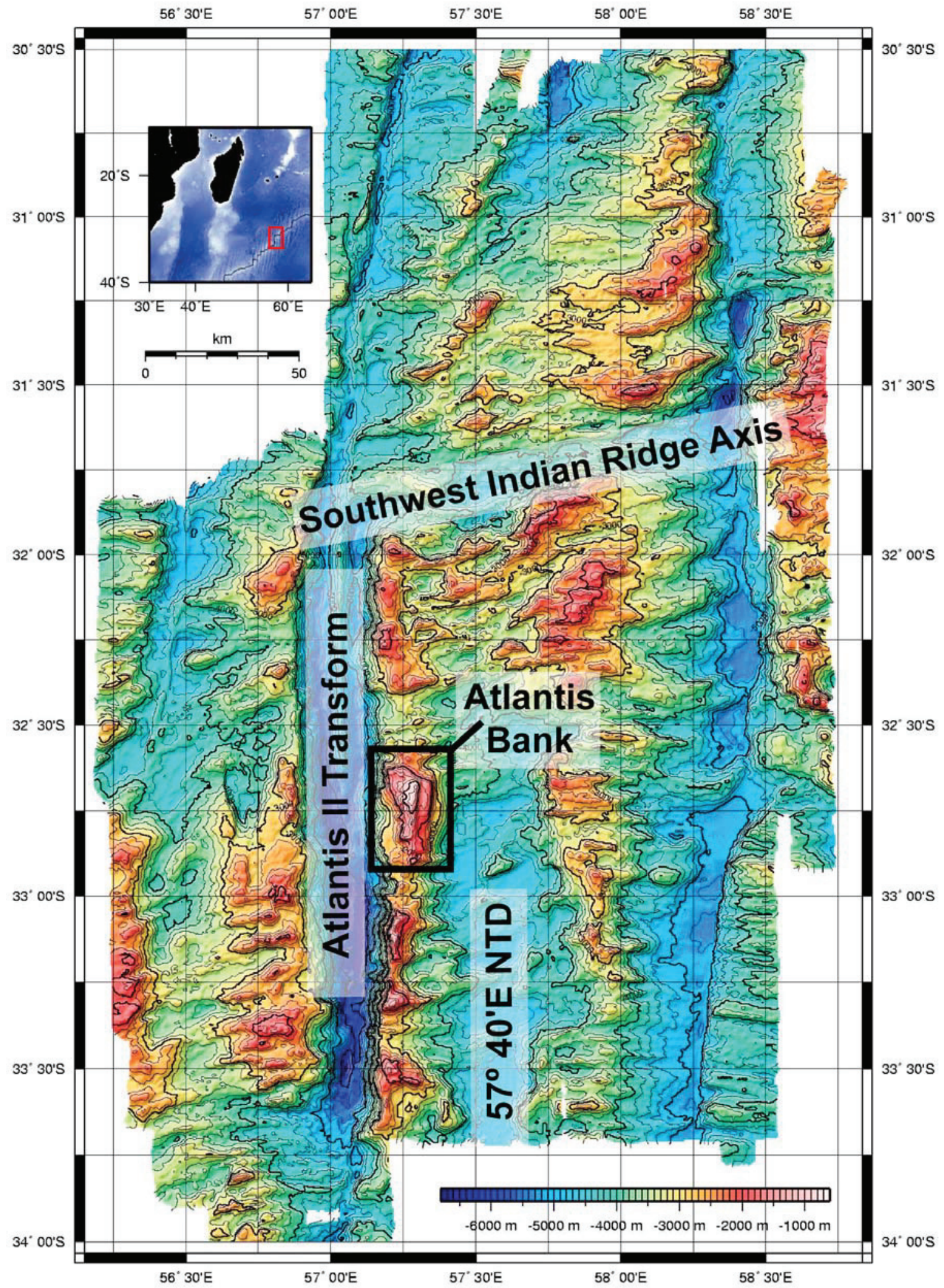

Figure 1. Bathymetric map of the Atlantis Bank region, showing the core complex as a bathymetric high characterized by $>5000 \mathrm{~m}$ of relief between the transform valley floor and the top of the bank at $\sim 700 \mathrm{~m}$ below the sea surface. Color scale represents depth below sea surface (GMT map constructed by G. Baines using data from Matsumoto et al. [2002]). 


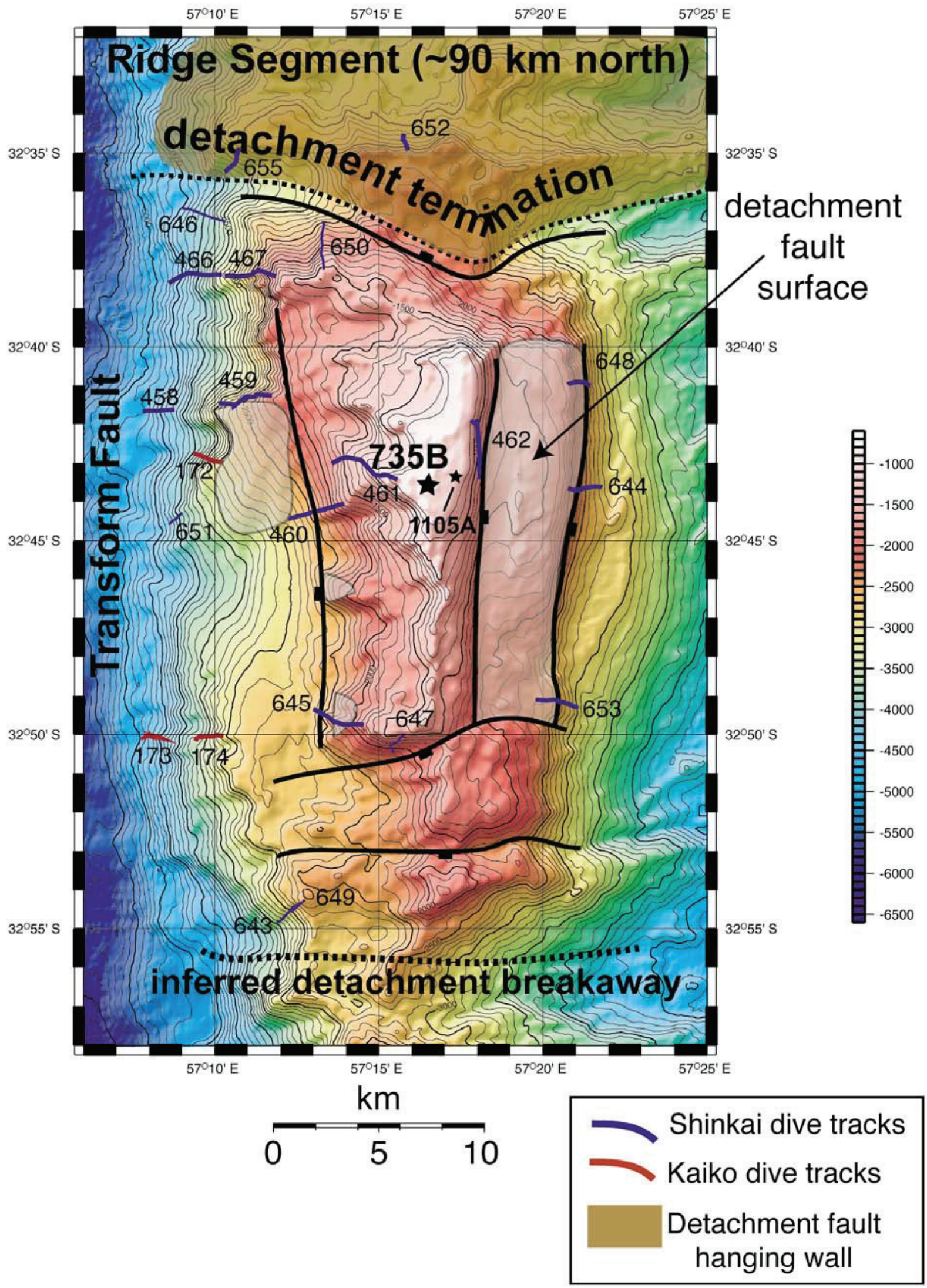

Figure 2 


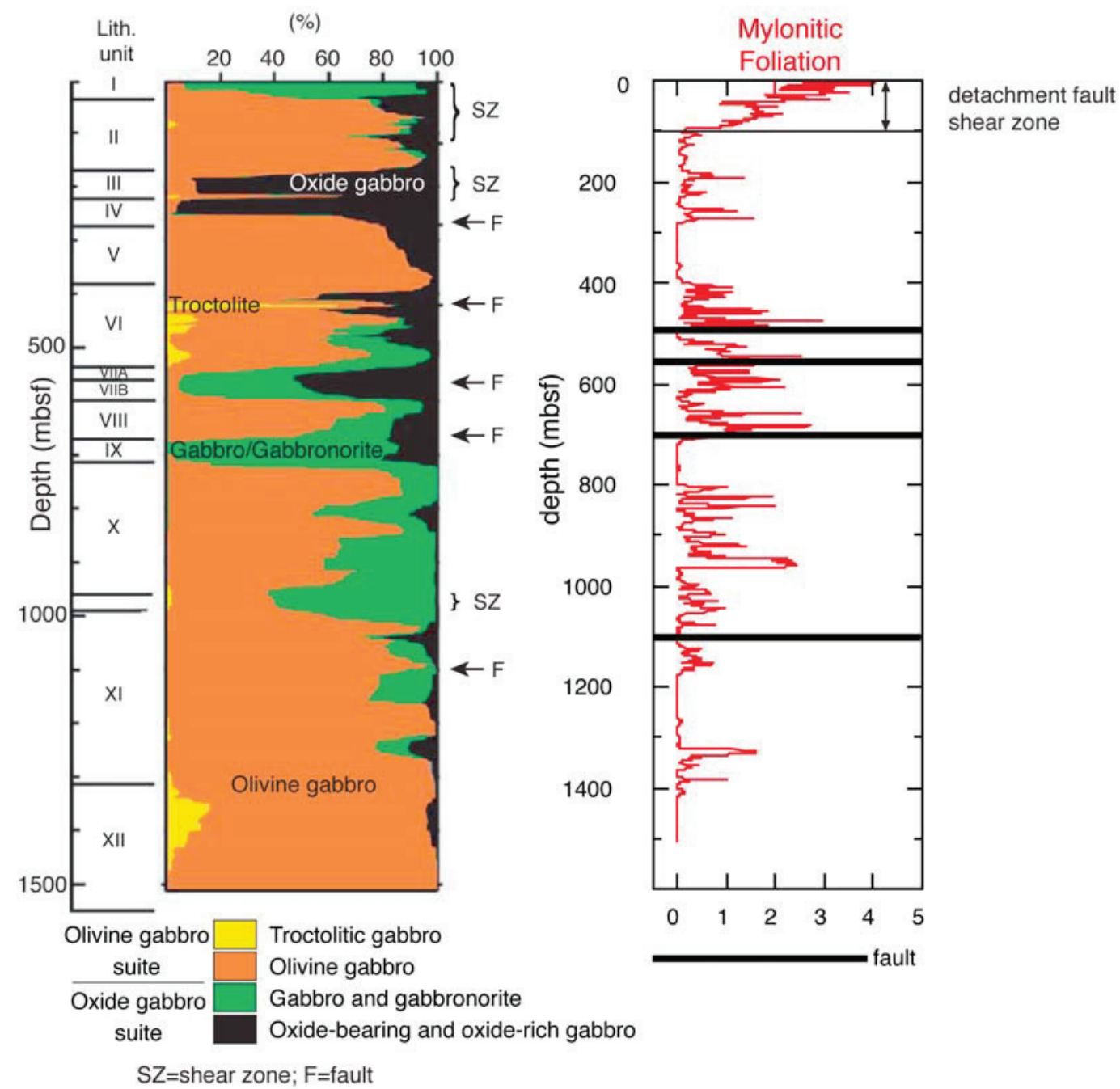

Figure 3. Lithostratigraphic composition and crystal plastic deformation intensity in ODP Hole $735 \mathrm{~B}$. The $\sim 100 \mathrm{~m}$ thick shear zone at the top of Hole 735B is structurally below the detachment fault surface and is defined by crystal plastic fabrics with intensity $>1$. The intensity of crystal plastic deformation is classified as follows [Cannat et al., 1991]: 1, weakly deformed, no penetrative foliation; 2 , penetrative foliation, dynamic recrystallization limited; 3 , well foliated, extensive dynamic recrystallization; 4, mylonitic bands ( $1 \mathrm{~mm}$ ), extensive dynamic recrystallization; 5 , mylonitic foliation, extensive dynamic recrystallization. Modified from Natland and Dick [2002].

categorized as "on outcrop"; they were lifted out of their location within the outcrop using the robotic arms of the submersible. Finally, loose samples collected from talus piles or from sediment-covered seafloor surfaces were described as "float." We designate "from outcrop" and "on outcrop" samples as in situ samples. A complete discussion of sample acquisition techniques and cruise results are discussed by Arai et al. [2000],

Figure 2. Bathymetric map of Atlantis Bank. The fault system and footwall are exposed over $300 \mathrm{~km}^{2}$. Denudation of hanging wall rocks (shaded brown) exposed a dome-shaped footwall, much of which has been dissected by both transform- and ridge-parallel normal faults. Remnants of the dome-shaped detachment fault surface are shaded light gray. The hanging wall initially separated from the footwall at the inferred breakaway; the leading edge of the hanging wall that slipped is now at the detachment termination. Atlantis Bank has been extensively sampled; Figure 2 shows the location of ODP Hole 735B and ODP 1105A, manned submersible dives (Shinkai dives in blue), and unmanned submersible dives (Kaiko dives in red) (GMT map constructed by G. Baines using data from Matsumoto et al. [2002]). 
Kinoshita et al. [2001], and Matsumoto et al. [2002].

\subsection{Sample Selection, Preparation, and Analytical Methods}

[10] Preliminary hand sample and microstructural observations were made on all in situ samples collected by University of Wyoming shipboard scientists from the 3 cruises; these include 67 samples from the 2001-2002 ABCDE cruise, 29 samples from the Mode '98 cruise, and 2 samples from the MODE 2000 cruise (Table 1). A detailed description of our sample selection criteria is located in the auxiliary material. ${ }^{1}$ A subset of 17 gabbroic rocks was chosen for detailed analyses based on well-developed, representative microstructures and mineral assemblages appropriate to document the T-t deformation associated with the development of the detachment system. A summary of the characteristics of these samples is included in Table 2. Their protoliths range in composition from olivine gabbro, oxide gabbro, oxide olivine gabbro, biotite hornblende oxide gabbro, hornblende gabbro and gabbro (following the nomenclature outlined by Shipboard Scientific Party [1999b]), and are characteristic of the rock types recovered in ODP holes $735 \mathrm{~B}$ and 1105A. The submersible samples allow both evaluation and comparison of strain localization processes between oxide and nonoxide gabbro suites (Figure 3).

[11] Dive samples were cut perpendicular to foliation and parallel to lineation when possible to allow characterization of textural development within the motion plane. Detailed interpretation of fabric development for the subset samples was accomplished by petrographic, microstructural, and electron microprobe (EPMA) analyses.

\subsection{Fabric Intensity Estimates}

[12] Metamorphic grade and intensity of fabric development within the ductile, semibrittle and brittle regimes were documented for each in situ sample collected along individual dive tracks, and are given in Table 1. For each sample, the fabric intensity is classified on a scale from 0 (lowest) to 5 (highest). For ductile fabrics, the intensity of deformation is based on the degree of grain size reduction and mylonitic foliation development, and follows from the shipboard classification used for

\footnotetext{
${ }^{1}$ Auxiliary material data sets are available at ftp://ftp.agu.org/ apend $/ \mathrm{gc} / 2009 \mathrm{gc} 002646$. Other auxiliary material files are in the HTML.
}

core from ODP Hole 735B [Shipboard Scientific Party, 1999b; Dick et al., 2000]. Mylonitic fabric development is classified based on the relative proportions of matrix and porphyroclasts [Spry, 1969; Sibson, 1977], and listed from 0 (undeformed) to 5 (ultramylonite). The intensity of semibrittle deformation is based on the degree of fracturing and syntectonic mineral growth; the intensity of brittle deformation is based on the percentage of grain size reduction from brittle fracturing after Schroeder and John [2004].

\subsection{Deformation Temperature Estimates}

\subsubsection{Qualitative and Quantitative Temperature Estimates}

[13] Deformation fabrics and mineral assemblages were described in thin section. Temperature estimates for the development of each texture were made on the basis of mineral assemblages and the microstructures developed in the constituent minerals [Brodie and Rutter, 1985]. These qualitative deformation temperature estimates were then compared to quantitative temperature determinations made on the 17 sample subset using mineral thermometry.

\subsubsection{Thermometry Methods}

[14] Plagioclase, amphibole, pyroxene and chlorite mineral compositions were determined using the JEOL JXA-8900 electron microprobe at the University of Wyoming. Temperatures were calculated for granulite grade mylonites using two-pyroxene QUIIF thermometry [Frost et al., 1988; Frost and Lindsley, 1992; Lindsley and Frost, 1992; Andersen and Lindsley, 1993] on adjacent pairs of recrystallized orthopyroxene and clinopyroxene neoblasts, and for amphibolite grade mylonites using the edenite-richterite amphibole-plagioclase thermometer [Holland and Blundy, 1994] on adjacent grains of amphibole and recrystallized plagioclase. We use this thermometer because it is calibrated for both silica-saturated and silicaundersaturated rocks in the temperature range of $500-900^{\circ} \mathrm{C}$, with plagioclase compositions of $\mathrm{X}_{\mathrm{An}}>0.1$ and $<0.9$. Temperatures were calculated for greenschist grade deformation using chlorite thermometry [Cathelineau, 1988; Jowett, 1991] on chlorite grains in the matrix material of mylonites and microbreccias. Complete descriptions of analytical procedures, thermometry calculations, sources of error, and mineral analyses are included in 


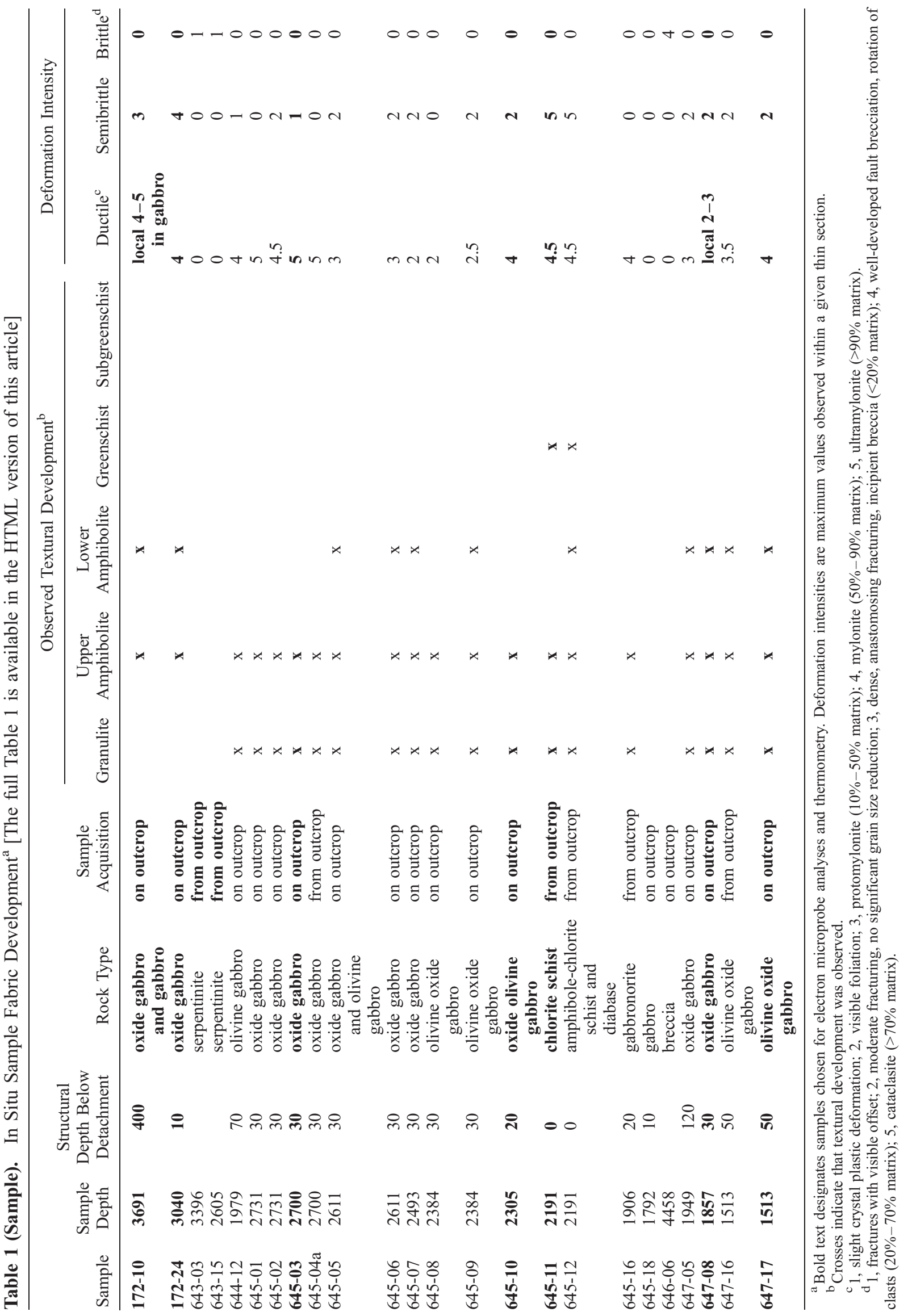




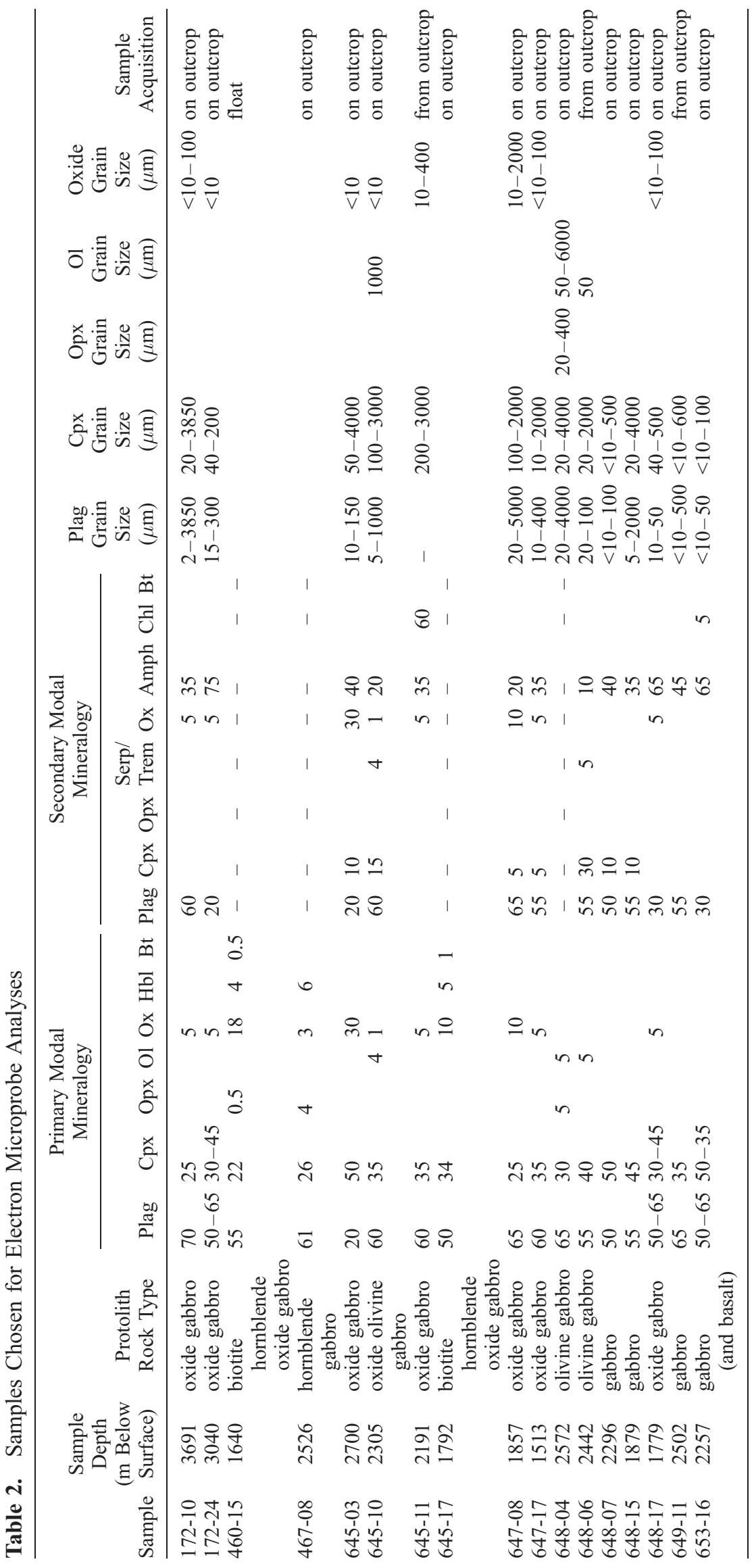



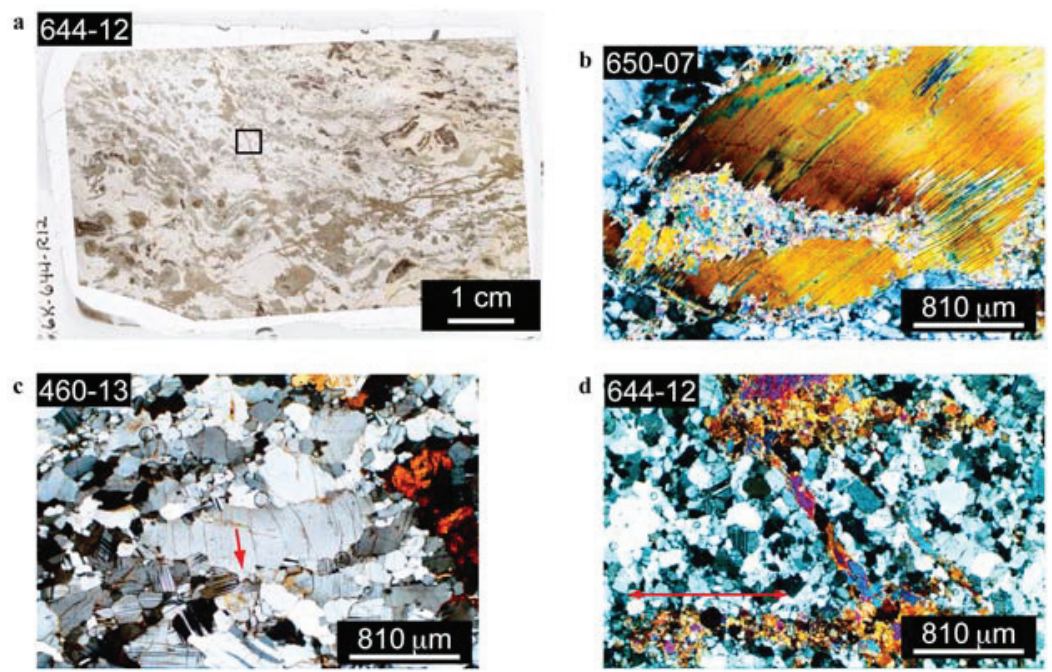

Figure 4. Photomicrographs showing textures indicative of granulite grade deformation. The box shows the location of area photographed in Figure 4d. (a) Plane light image of sample 644-12 showing the orientation of foliation. (b) In sample 650-07, a kinked clinopyroxene porphyroclast exhibits undulose extinction and is mantled by pyroxene neoblasts. (c) In sample 460-13, an elongate plagioclase grain exhibits bulging grain boundaries (red arrow). (d) In sample 644-12, brown amphibole-filled fractures cut obliquely across the protomylonitic foliation (double-headed arrow).

the auxiliary material and described separately by Miranda [2006].

\section{Results}

\subsection{Microstructural Fabric Description}

[15] Our microstructural observations and calculations of average deformation intensity suggest that gabbroic rock samples are more intensely deformed than serpentinized peridotite within the ductile, semibrittle, and brittle regimes (Table 1). Owing to the essentially undeformed ultramafic samples, we then focused our investigation on 17 samples of minimally to intensely deformed olivine gabbro, oxide gabbro, oxide olivine gabbro, biotitehornblende oxide gabbro, hornblende gabbro and gabbro (Table 2). These samples were collected from as deep as $600 \mathrm{~m}$ below the present detachment fault surface, and over a distance $\sim 22 \mathrm{~km}$ along a lithospheric flow line and $\sim 20 \mathrm{~km}$ parallel to the strike of the axial valley. The samples display textures characteristic of fabric development (based on mineral deformation mechanisms) at granulite, amphibolite, greenschist and subgreenschist grade temperatures.

\subsection{Microstructures Developed During Granulite Grade Deformation}

[16] Granulite grade $\left(800-950^{\circ} \mathrm{C}\right)$ metamorphic assemblages in mafic rocks typically include oliv- ine + clinopyroxene + orthopyroxene + plagioclase \pm magnetite \pm ilmenite \pm apatite. In low-strain granulite grade protomylonites, the incipient foliation is manifested by alternating layers of pyroxene and plagioclase (Figure 4a). Some clinopyroxene porphyroclasts are kinked or folded and mantled by coarse-grained recrystallized neoblasts (Figure 4b). Magmatic plagioclase exhibits serrated grain boundaries mantled by recrystallized neoblasts (Figure 4c), similar to microstructures associated with regime 3 high-temperature grain boundary migration deformation in quartz [Hirth and Tullis, 1992; Post and Tullis, 1999].

[17] Brown amphibole-filled fractures locally cut obliquely across the foliation in some granulite grade samples (Figure 4d). The orientation of the protomylonitic foliation is not disturbed by the amphibole-filled fractures, but the mineral phases that define compositional foliation change with proximity to the fractures. Nearest the fractures, the protomylonitic foliation is manifested by alternating layers of brown amphibole and plagioclase. With increasing distance $(>1 \mathrm{~cm})$ away from the fractures, the protomylonitic foliation is defined by alternating pyroxene and plagioclase layers, suggesting that amphibole replaces pyroxene.

[18] A well-developed mylonitic foliation is defined by alternating layers of recrystallized plagioclase and pyroxene porphyroclasts in high-strain granulite grade mylonites (Figure 5a). Both clino- 

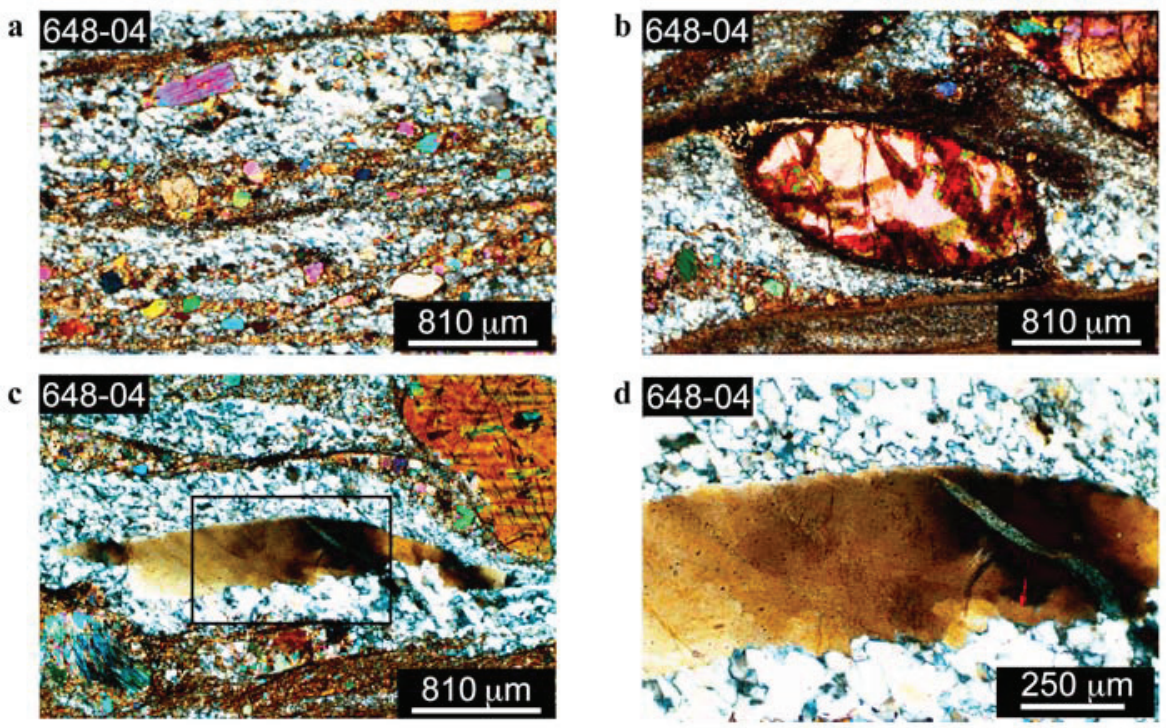

Figure 5. Photomicrographs showing granulite grade textures in sample 648-04. (a) Compositionally banded foliation. (b) Asymmetric olivine fish. (c) Elongate plagioclase porphyroclast mantled by recrystallized grains define an oblique foliation. (d) Close-up photo from Figure 5c showing subgrain development (red arrow) along the margins of the porphyroclast.

pyroxene and orthopyroxene porphyroclasts are bent, resulting in folded cleavage planes and exsolution lamellae. These porphyroclasts typically show sweeping extinction and are mantled with equant recrystallized neoblasts (Figure 5a). Within the foliation, lozenge-shaped olivine porphyroclasts with sweeping extinction and subgrain development are sometimes observed (Figure 5b). Plagioclase is extensively recrystallized, and few porphyroclasts remain. The margins of elongate porphyroclasts contain subgrains similar in size to adjacent recrystallized grains (Figure $5 \mathrm{c}$ ), indicative of regime 2-style subgrain rotation recrystallization [Hirth and Tullis, 1992]. The recrystallized grains (former subgrains) exhibit bulging grain boundaries, similar to microstructures indicative of regime $1-$ style bulging recrystallization. The recrystallized plagioclase neoblasts surrounding the elongate porphyroclasts locally form foliation oblique to the compositional banding (Figure 5d).

\subsection{Microstructures Developed During Amphibolite Grade Deformation}

[19] Upper amphibolite grade deformation is characterized by the assemblage plagioclase + brown amphibole \pm pyroxene \pm magnetite \pm ilmenite \pm sphene \pm apatite. A well-developed compositionally layered mylonitic foliation is defined by alternating layers of recrystallized plagioclase and amphibole (Figure 6a). Amphibole porphyroclasts are commonly mantled by amphibole neoblasts. We also observe rare amphibole porphyroclasts with cores of relict pyroxene, and infer that the mantled amphibole porphyroclasts were originally pyroxene porphyroclasts (Figure 6b).

[20] In upper amphibolite grade mylonites, the coarsest $(>2 \mathrm{~mm})$ plagioclase porphyroclasts are elongate with extensive undulose extinction and deformation twinning. Microfaults across these large porphyroclasts truncate deformation twins and locally exhibit neoblast development along their traces (Figure $6 \mathrm{c}$ ). Large $(\sim 1 \mathrm{~mm})$, angular, elongate plagioclase porphyroclasts (Figure 6d) exhibit subgrain development in narrow $(\sim 50$ $\mu \mathrm{m})$ zones along grain boundaries, and are surrounded by a matrix of very fine grained $(\sim 10 \mu \mathrm{m})$ neoblasts. Matrix neoblasts are similar in size to the subgrains, and show bulging grain boundaries indicative of regime 1 -style bulging grain boundary migration recrystallization [Hirth and Tullis, 1992].

[21] Amphibole schists are also characteristic of upper amphibolite grade deformation. In these schists, abundant light brown amphibole exhibits a strong grain shape preferred orientation that defines the schistose foliation (Figure 7a). Finegrained $(\sim 50 \mu \mathrm{m})$ tabular amphibole does not display undulose extinction, deformation twins, bulging grain boundaries or other microstructural evidence of crystal plastic deformation (Figure 7b). Plagioclase, when present, is confined to foliationparallel lensoid-shaped regions (Figure $7 \mathrm{~b}$ ). The 

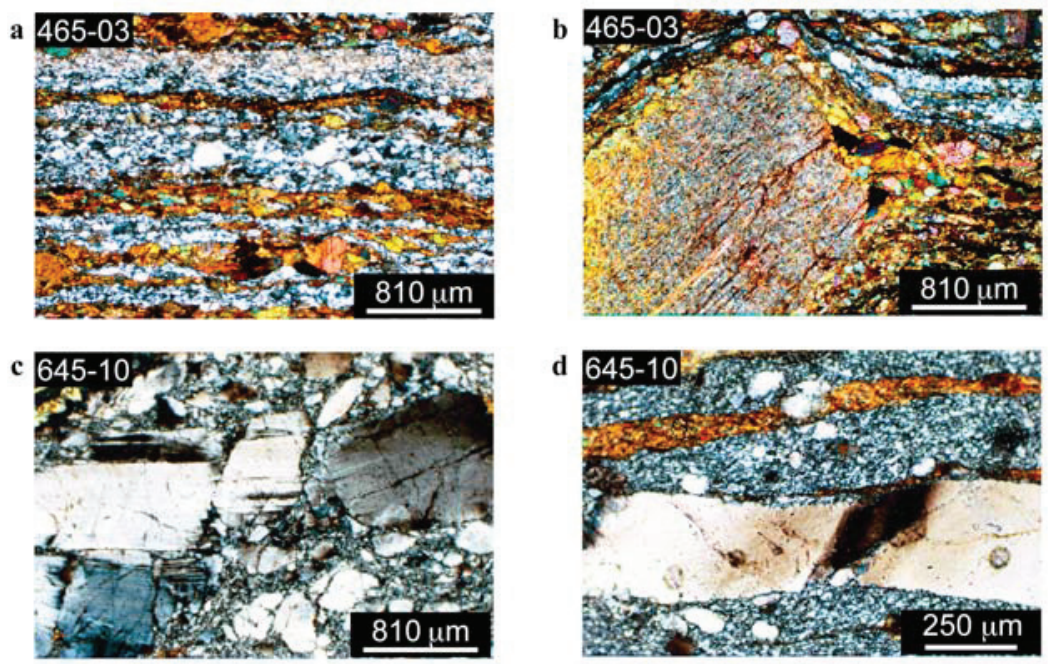

Figure 6. Photomicrographs showing microstructures associated with upper amphibolite grade deformation. (a) Sample 465-03 contains a foliation defined by alternating bands of brown amphibole and plagioclase. (b) An amphibole porphyroclast with a core of relict pyroxene from sample 465-03. (c) In sample 645-10, an elongate plagioclase porphyroclast is microfaulted. (d) In sample 645-10, an elongate plagioclase porphyroclast exhibits core and mantle structure.

plagioclase grains rarely form porphyroclasts; rather the grains are extremely fine grained $(\sim 10 \mu \mathrm{m})$ and exhibit bulging grain boundaries indicative of regime 1 -style bulging grain boundary migration recrystallization [Hirth and Tullis, 1992].
[22] Fractures oblique to the schistose foliation are partially filled by Fe-Ti oxide minerals and sphene (Figure 7c), and show little offset of the foliation across the fracture (Figure 7d). Locally, amphibole has grown parallel to foliation across the fractures
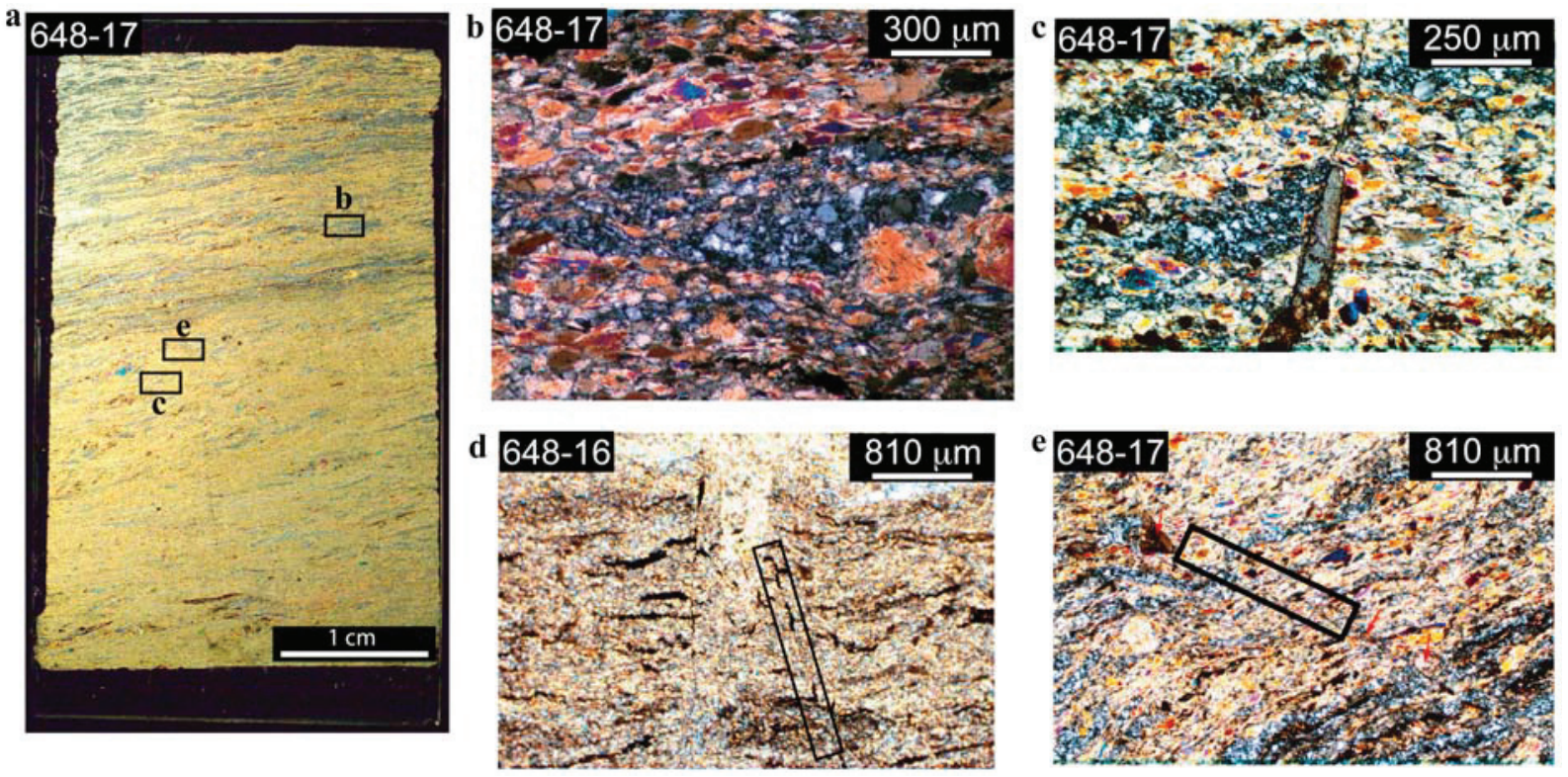

Figure 7. Photomicrographs showing textures observed in amphibole schists. (a) Cross-polarized image of thin section from sample 648-17. The brownish-gold colored regions are amphibole-rich areas; the gray regions are dominated by plagioclase. The locations of Figures $7 \mathrm{~b}, 7 \mathrm{c}$, and $7 \mathrm{e}$ are designated by the black boxes. (b) A lensshaped region of recrystallized plagioclase is surrounded by strongly oriented, tabular amphibole in sample 648-17. (c) A sphene-filled fracture cuts at high angle across the foliation. (d) Oxide-filled fractures (enclosed by black box) in amphibole schist sample 648-16 also cut at high angle to the foliation. (e) A partially healed fracture in sample 648-17 (enclosed by black box) cuts obliquely across the foliation. Sphene grains (red arrows) remain oriented in the trend of the former fracture. 


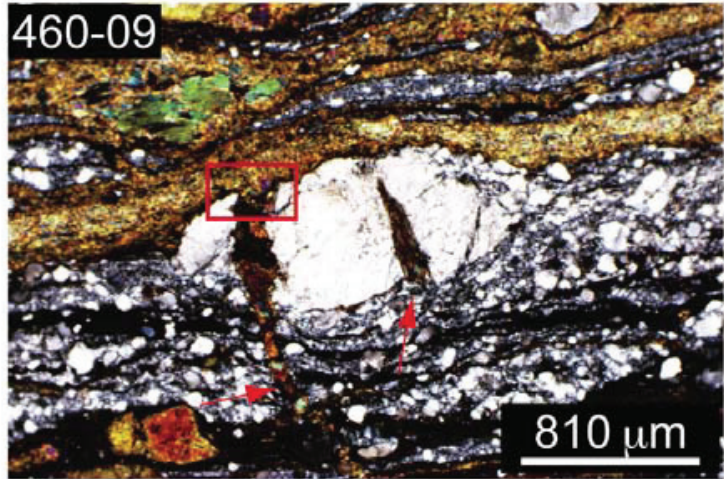

Figure 8. Photomicrograph showing fabric observed in middle amphibolite grade mylonitic shear zone. In sample 460-09, amphibole-filled microfaults are cut by the matrix of recrystallized plagioclase grains surrounding the porphyroclast (red arrow at right). A different amphibole-filled fracture (red arrow at left) cuts across the plagioclase porphyroclast and the surrounding recrystallized matrix; it does not, however, cut across the finely recrystallized amphibole zone (red box).

that do not contain oxide minerals or sphene, and effectively conceal portions of the fracture trace. We infer the existence and orientation of former fractures by the presence of linear trails of fracturefilling minerals that are not incorporated into the schistose foliation (Figure 7e).

[23] Middle amphibolite grade deformation is characterized by the assemblage plagioclase + brown amphibole \pm olive green amphibole \pm magnetite \pm ilmenite \pm sphene \pm apatite. Mylonitic foliation is manifested by compositional layering of dynamically recrystallized plagioclase and brown amphibole, and the absence of relict pyroxene in the cores of amphibole porphyroclasts. Evidence for crystal plastic deformation of plagioclase and amphibole is largely similar to that observed in upper amphibolite grade mylonites, barring evidence for semibrittle deformation in the mylonites. Large $(>2$ $\mathrm{mm}$ ) fragmented plagioclase porphyroclasts with parallel sets of amphibole-filled microfaults are common (Figure 8). These amphibole-filled fractures commonly cut across plagioclase porphyroclasts and their surrounding matrix of fine-grained recrystallized plagioclase, but not adjacent layers of amphibole neoblasts (Figure 8). We infer that the sinuous grain boundaries of amphibole neoblasts indicate crystal plasticity and grain boundary mobility leading to local fracture healing within amphibole layers. The crosscutting relationships imply multiple fracture events during dynamic recrystallization.
[24] Lower amphibolite grade mylonitic fabrics are defined by alternating layers of recrystallized olive green amphibole and plagioclase (Figure 9a). Synkinematic alteration of brown amphibole porphyroclasts to olive green amphibole is indicated by porphyroclast cores of brown amphibole being increasingly altered to olive green amphibole toward the rim, and are mantled by green amphibole

a

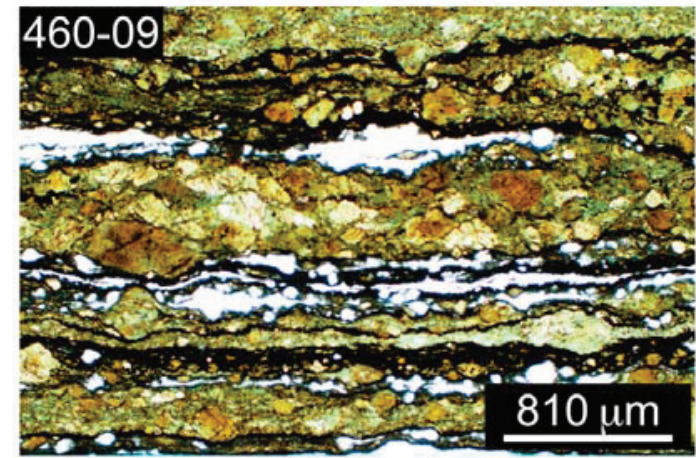

b

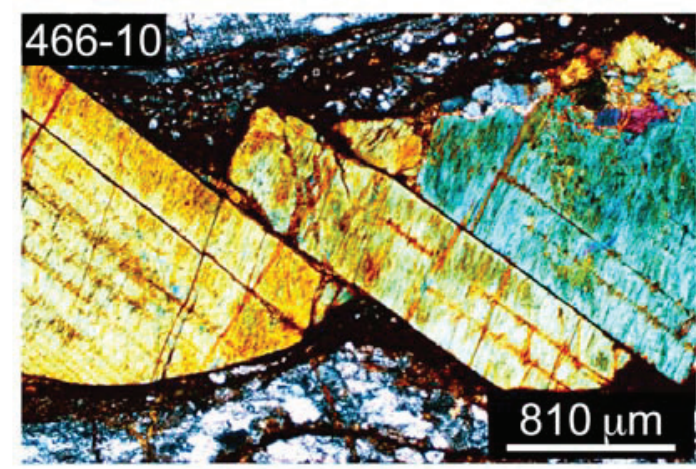

c

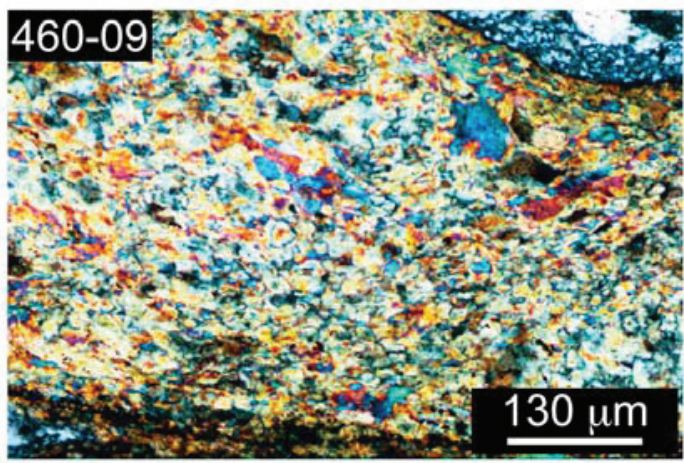

Figure 9. Photomicrographs showing microstructures observed in lower amphibolite grade samples. (a) Plane light image of sample 460-09 showing well-developed, compositionally layered foliation, manifested by alternating bands of plagioclase and olive green amphibole. The larger amphibole porphyroclasts have brown cores and olive green rims, indicative of down-temperature synkinematic growth. (b) A large fragmented amphibole (after pyroxene) porphyroclast in sample 466-10 exhibits microfaults. (c) Recrystallized amphibole grains exhibit bulging grain boundary migration recrystallization structures in sample 460-09. 

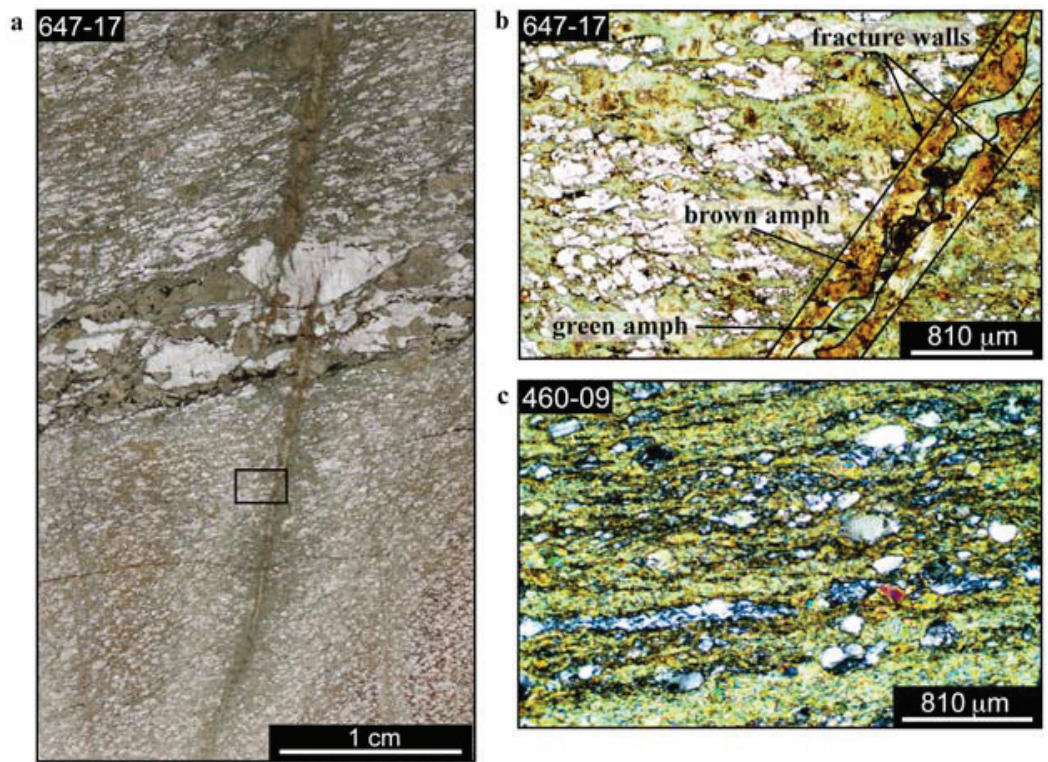

Figure 10. Microstructures observed in lower amphibolite grade samples. (a) Plane light image of mylonitic fabric in sample 647-17. Large amphibole-filled veins cut the mylonitic foliation. Amphibole growth in the foliation is more extensive within $0.5 \mathrm{~cm}$ of the fracture. The location of Figure $10 \mathrm{~b}$ is designated by the black box. (b) The fracture walls are lined with brown amphibole; green amphibole fills the center of the fracture. Large amphibole porphyroclasts within the foliation are zoned with light brown amphibole in the core and green amphibole on the rim. (c) Cross-polarized image of spaced foliation in lowest amphibolite grade shear zone within sample 460-09. Lensshaped regions of recrystallized plagioclase are enveloped by fine-grained green amphibole.

neoblasts. Large ( $>2 \mathrm{~mm})$ amphibole grains form fragmented porphyroclasts offset along parallel microfaults (Figure 9b). Mantled amphibole porphyroclasts exhibit asymmetric wings of amphibole neoblasts that extend from porphyroclast wings, and help define the amphibole layers of the compositional foliation. Amphibole neoblasts exhibit bulging grain boundaries (Figure 9c) that resemble regime 1-style dynamic recrystallization [Hirth and Tullis, 1992], which we interpret to result from extensive amphibole recrystallization.

[25] Amphibole-filled fractures that cut obliquely across lower amphibolite grade mylonitic foliation (Figure 10a) are lined with brown amphibole, whereas the fracture centers are filled with green amphibole (Figure 10b). Extensive foliation-parallel amphibole lies in the mylonitic foliation nearest the fractures, but decreases away from these planes. Lens-shaped regions of recrystallized plagioclase are enveloped by green amphibole adjacent to the fractures and by brown amphibole further away $(>0.5 \mathrm{~cm})$. At lowest amphibolite grade temperatures, the foliation development is defined by lens-shaped domains of recrystallized plagioclase enveloped by anastomosing bands of finegrained amphibole (Figure 10c). The fine-grained domains of plagioclase resemble the matrices of recrystallized neoblasts observed around porphyroclasts in higher-grade mylonites. The abundant amphibole isolates the lens-shaped regions of recrystallized plagioclase, creating an interconnected network of amphibole.

\subsection{Microstructures Developed During Greenschist and Subgreenschist Grade Deformation}

[26] Greenschist grade metamorphic assemblages include green amphibole + epidote + chlorite + plagioclase \pm sphene \pm apatite. Brittle greenschist grade deformation is manifested by prehnite-, epidote-, and serpentine-filled fractures across granulite and amphibolite grade mylonitic fabric. Semibrittle greenschist grade deformation is manifested in the growth of amphibole, chlorite and epidote at the expense of plagioclase.

[27] In samples 467-19 and 650-16, plagioclase cores are rimmed with fine-grained chlorite, epidote and amphibole (Figures 11a and 11b). These replacement textures are also observed in greenschist grade gabbro mylonites, though the alteration was complete or nearly complete, and the chlorite 

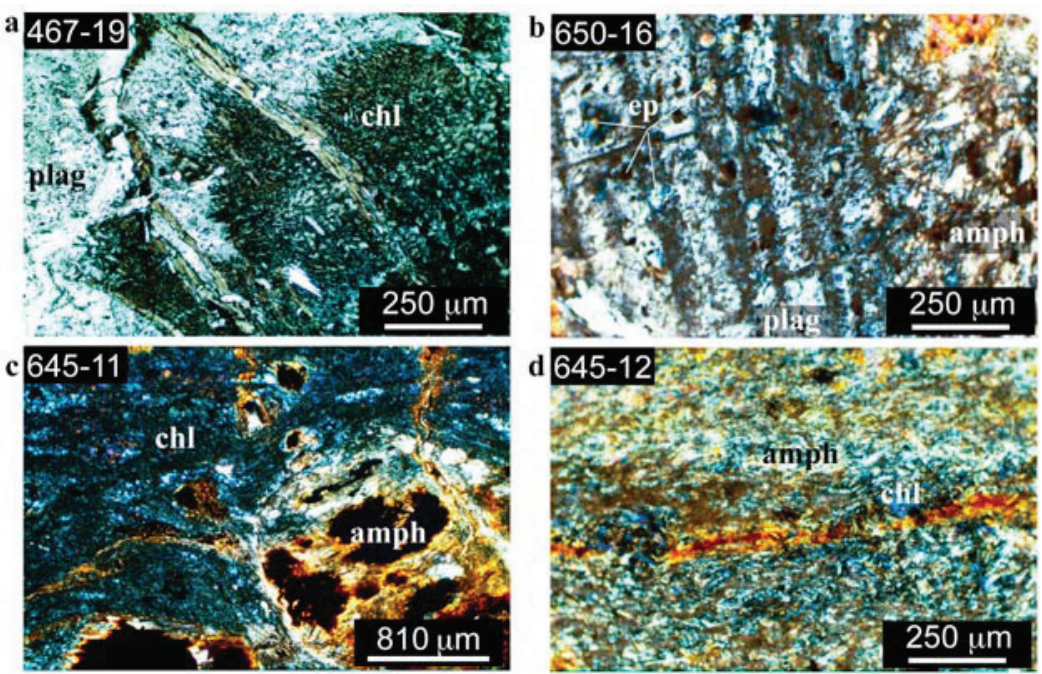

Figure 11. Photomicrographs showing greenschist grade textures. (a) In undeformed gabbro sample 467-19, chlorite replaces plagioclase on the margins of a plagioclase grain. (b) In undeformed gabbro sample 650-16, epidote replaces plagioclase in grain centers. (c) A relict high-temperature mylonitic fabric is preserved in sample 645-11. Chlorite forms the matrix around an asymmetric amphibole porphyroclast. (d) In sample 645-12, fine-grained chlorite and amphibole define the schistosity.

and epidote often show semibrittle or brittle deformation. Mylonitic foliations comprising alternating layers of amphibole porphyroclasts and finegrained chlorite or epidote (Figure 11c), are inferred as relict high-temperature mylonites, based on the well-rounded, coarse-grained porphyroclastic texture of the amphibole grains. Comparison with compositional foliation in upper amphibolite grade mylonites suggests that the layers of chlorite and epidote in sample 650-16 were once layers of dynamically recrystallized plagioclase. Amphibole-chlorite schists (Figure 11d), contain finegrained amphibole and chlorite that exhibit a strong grain shape preferred orientation, but little evidence for crystal plastic deformation of either mineral.

[28] Subgreenschist grade samples are variably altered and intensely deformed within the brittle regime. Clast- and/or matrix-supported fault breccias contain clasts of amphibolite grade mylonites (Figure 12a), amphibolite grade fault schists (Figures $12 \mathrm{~b}$ and $12 \mathrm{c}$ ), greenschist grade fault schists, and diabase. The amphibole and chlorite schist clasts retain their internal schistose texture defined by the grain shape preferred orientation of amphibole. Though plagioclase is extremely rare in the relict schistose foliation of these highly altered clasts, a few clasts preserve the compositional banding of amphibole and plagioclase characteristic of amphibole schists (Figures $12 \mathrm{~b}$ and 12c).
Pumpellyite and chlorite commonly make up to $50 \%$ of the matrix between clasts and give the fault breccias a green color in thin section and hand sample. Clast size varies from $\sim 2 \mathrm{~mm}$ to clay-sized particles, indicating substantial mechanical grain size reduction. In clast-supported breccias, visible offset can be observed across fractures. In matrixsupported breccias, clasts show rotation relative to one another.

\section{Mineral Chemistry and Thermometry}

[29] Mineral compositions (pyroxene, plagioclase, amphibole and chlorite) from 17 samples were analyzed to estimate temperatures associated with all grades of fabric development, and are listed in the auxiliary material.

\subsection{Mineral Chemistry}

[30] Clinopyroxene is augitic in composition, with orthopyroxene more $\mathrm{Mg}$-rich relative to $\mathrm{Fe}$. Amphibole data define a linear trend from actinolite to pargasite compositions on a plot of $\mathrm{Al}^{\mathrm{IV}}$ cations versus alkali $(\mathrm{Na}+\mathrm{K})$ cations (Figure 13). Plagioclase composition varies over the entire data set from $\mathrm{An}_{88}$ to $\mathrm{An}_{7}$, whereas the average $\mathrm{An}$ composition for each sample varies from $\mathrm{An}_{61}$ to $\mathrm{An}_{17}$. The average, median, maximum, and minimum An composition for plagioclase compositions are shown in Table 3. 
a

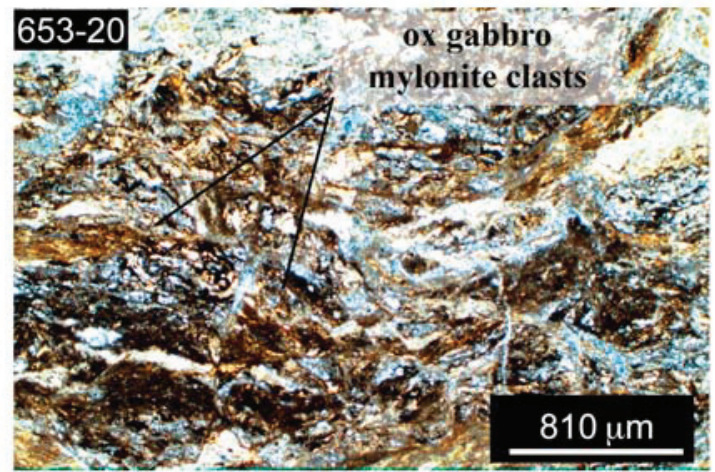

b

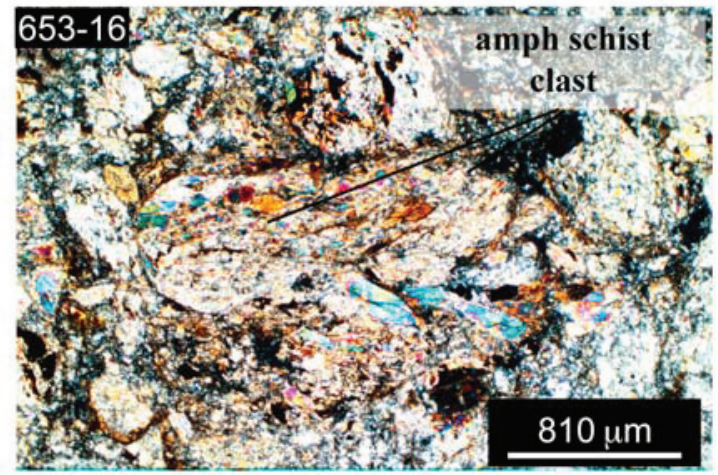

c

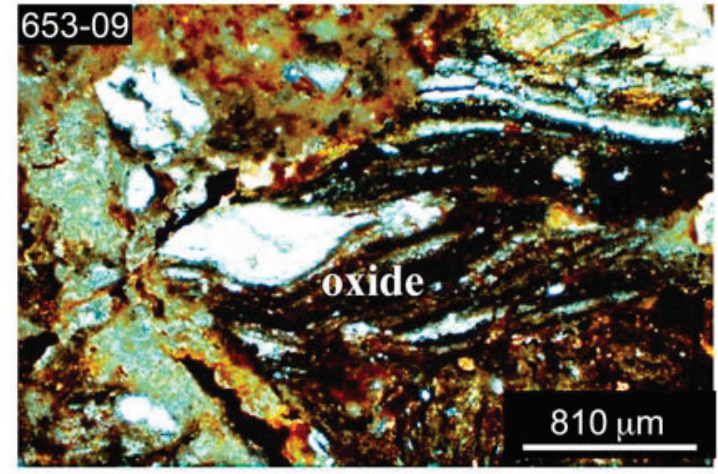

Figure 12. Photomicrographs showing fault breccia fabric development. (a) Sample 653-20 contains clasts of oxide gabbro mylonite; they are identified by oxiderich relict foliation. (b) Sample 653-16 contains clasts of amphibole schist. The amphibole in the clasts is similar in appearance to that in amphibole schist samples 64817 and 648-16. (c) Clasts of amphibole schist in sample 653-16 contain oxide-filled fractures at high angle to the relict foliation, also similar to textures in samples 64817 and 648-16.

\subsection{Thermometry}

[31] In situ samples exhibiting distinctive textures described above for granulite, amphibolite and greenschist grade deformation were selected for temperature estimates using two-pyroxene QUIIF, amphibole-plagioclase, and chlorite thermometry (auxiliary material), and help quantify the downtemperature evolution of detachment fault evolution.

[32] Temperatures associated with granulite grade fabric development were estimated using twopyroxene QUIIF thermometry on sample 648-04 (Figure 14). Two-pyroxene thermometry from orthopyroxene and clinopyroxene neoblast pairs indicates dynamic recrystallization of pyroxene occurred at temperatures ranging from 862 to 910 $( \pm 20)^{\circ} \mathrm{C}$ (Table 4).

[33] Amphibole-plagioclase thermometry was used to estimate temperatures of deformation preserved in amphibolite grade compositionally banded mylonites, mylonites with spaced foliation, and amphibole schists (see Tables 5 and 6). Though all of these fabric types contain dynamically recrystallized plagioclase, not all contain dynamically recrystallized amphibole. Consequently, dynamically recrystallized amphibole and plagioclase pairs and undeformed amphibole and dynamically recrystallized plagioclase pairs were analyzed. In the case of the undeformed amphibole and dynamically recrystallized plagioclase pairs, calculated temperatures likely reflect the temperature of amphibole growth. Average temperatures from the entire data set range between 592 to $818( \pm 40)^{\circ} \mathrm{C}$.

[34] Estimated temperatures of mylonitization for gabbro sample 645-10 vary with fabric development associated with the early history of the detachment fault system; the compositionally layered protomylonitic fabric is overprinted by high-strain mylonitic shear zones (Figure 15). Amphibole and plagioclase porphyroclasts in the early protomylonitic fabric have an average temperature of $880 \pm$ $40^{\circ} \mathrm{C}$ (Figure 15d). In contrast, recrystallized amphibole rimming amphibole porphyroclasts and recrystallized plagioclase defining the mylonitic fabric yields a lower average temperature of $795 \pm$ $40^{\circ} \mathrm{C}$. Temperature estimates from very fine grained recrystallized amphibole and plagioclase in folded mylonitic fabric developed under an average temperature of $665 \pm 40^{\circ} \mathrm{C}$. These crosscutting relationships and thermometry therefore demonstrate down-temperature deformation consistent with denudation by normal faulting.

[35] Estimated temperatures associated with greenschist grade fabrics are based on chlorite thermometry. In sample 645-11, a static greenschist grade overprint of the high-temperature mylonitic foliation is manifested by near-complete replacement of plagioclase by chlorite. Chlorite within the foliation yields an average temperature of $328 \pm 50^{\circ} \mathrm{C}$ (Figure 16). In sample 653-16, chlorite- 


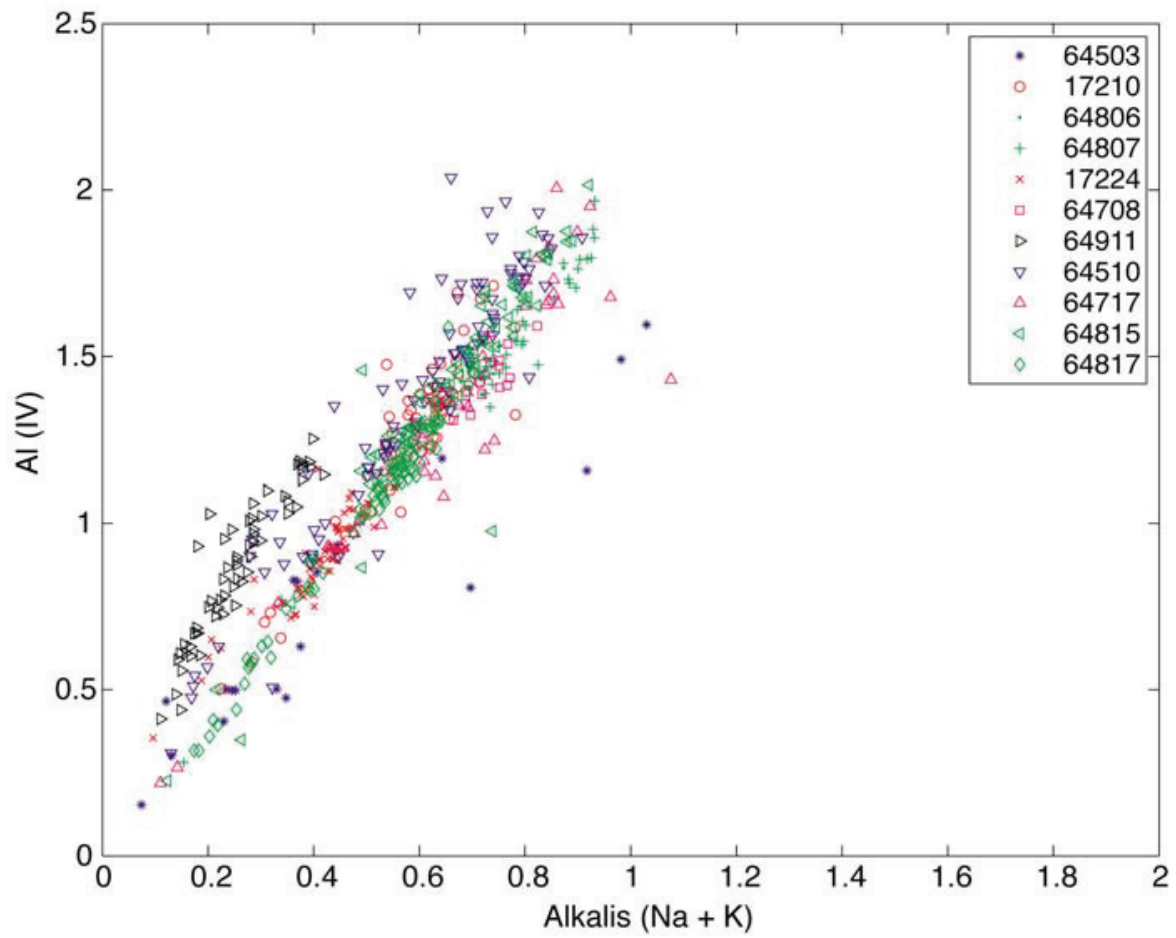

Figure 13. Amphibole chemistry based on total alkalis $(\mathrm{Na}+\mathrm{K})$ versus $\mathrm{Al}^{(\mathrm{IV})}$. The graph symbols are color coded by dive track: 172 (red), 645 (blue), 647 (pink), 648 (green), and 649 (black). The shape of the symbol is unique for each sample. Amphibole in samples 172-10, 172-24, 645-03, 645-10, 647-08, 647-17, 648-06, 648-07, 648-15, and $648-17$ is actinolitic to pargasitic in composition. The amphibole in sample 649-11 varies in composition from tremolite to magnesio-hornblende.

altered clasts in fault breccia yield a slightly lower average temperature of $303 \pm 50^{\circ} \mathrm{C}$, implying continued down-temperature deformation/fracturing and fluid flow. Representative chlorite analyses and accompanying temperature calculations are shown in Table 7.

\section{Discussion: Strain Localization Processes}

[36] In this study, we use in situ submersible samples to investigate fabric development associated with the localization of strain along the Atlantis Bank oceanic detachment fault system in concert with microstructural analyses and thermometry to describe a protracted history of down-temperature deformation and strain localization. Microstructures initially developed in granulite grade mylonites exposed at Atlantis Bank suggest that plagioclase is the rheologically weak mineral phase during deformation. Extensive dynamic recrystallization of plagioclase contributed to the development of a fine-grained matrix with competent pyroxene and olivine porphyroclasts that have undergone limited recrystallization at temperatures between 862 and $910( \pm 20)^{\circ} \mathrm{C}$. In rare instances, plagioclase porphyroclasts show textures suggestive of regime 2-style subgrain microstructures overprinting regime 1 -style bulg-

Table 3. Summary of Plagioclase Analyses Statistics

\begin{tabular}{|c|c|c|c|c|c|c|c|c|c|c|c|c|}
\hline & $172-10$ & $172-24$ & $645-03$ & $645-10$ & $647-08$ & $647-17$ & $648-04$ & $648-06$ & $648-07$ & $648-15$ & $648-17$ & $649-11$ \\
\hline Average An \# & 17 & 17 & 28 & 46 & 29 & 38 & 45 & 37 & 56 & 47 & 44 & 61 \\
\hline Median An \# & 17 & 17 & 35 & 46 & 30 & 38 & 45 & 36 & 39 & 48 & 44 & 61 \\
\hline Standard deviation & 4 & 4 & 9 & 4 & 7 & 9 & 2 & 4 & 24 & 4 & 4 & 6 \\
\hline Maximum An \# & 25 & 30 & 38 & 71 & 35 & 54 & 52 & 44 & 88 & 53 & 56 & 80 \\
\hline Minimum An \# & 9 & 7 & 16 & 39 & 7 & 12 & 41 & 27 & 14 & 30 & 30 & 48 \\
\hline Number of analyses & 79 & 80 & 25 & 140 & 33 & 45 & 162 & 30 & 40 & 80 & 81 & 60 \\
\hline
\end{tabular}



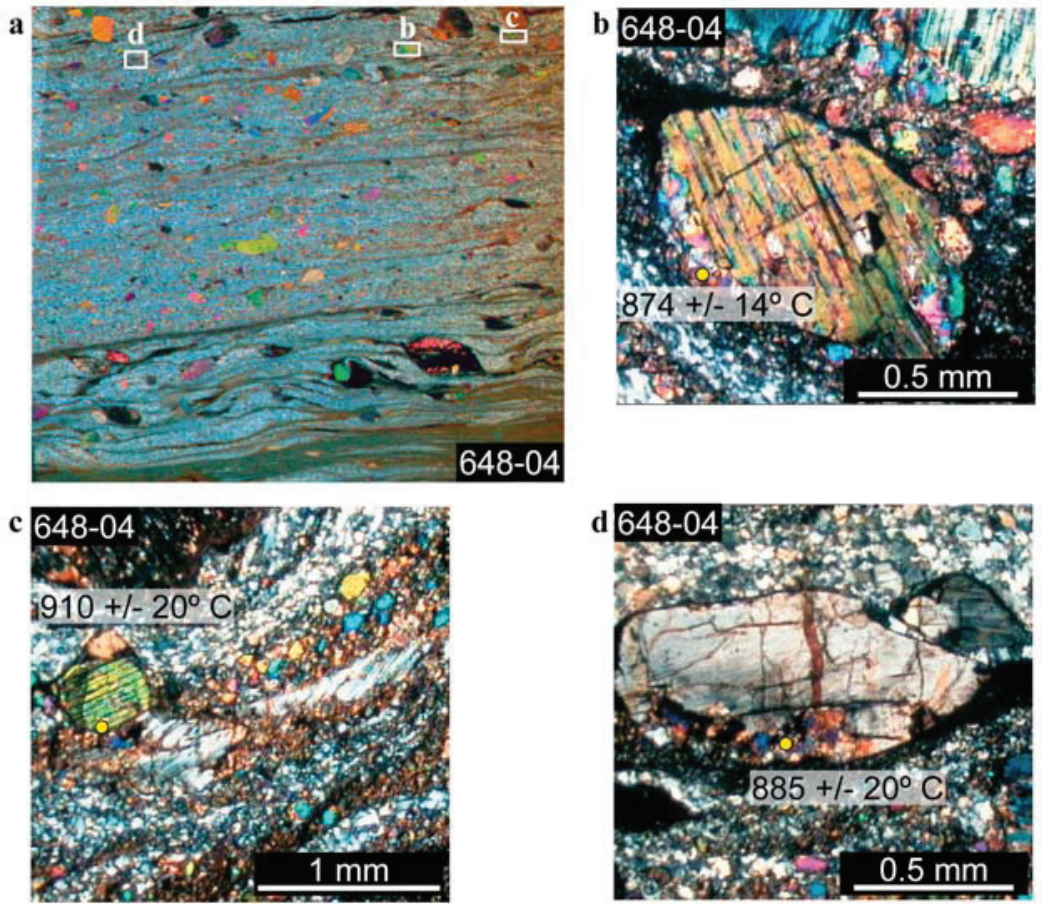

Figure 14. Regions of two-pyroxene QUILF thermometry analyses in sample 648-04. (a) Cross-polarized image of a portion of the thin section. (b) Cross-polarized image of area 4 (out of 7) pyroxene analyses area within the thin section $(n=53)$. (c) Cross-polarized image of area 5 region of pyroxene analyses $(n=40)$. (d) Cross-polarized image of area 6 region of pyroxene analyses $(n=29)$.

ing grain boundary migration microstructures, implying continued recrystallization during decreasing temperature or increasing strain rate conditions, consistent with progressive strain localization [e.g., Kohn and Northrup, 2009]. An interconnected network of one mineral phase has been found an effective means of controlling the rheology of a sample [Jordan, 1987; Handy, 1989]; similarly, we suggest that the plagioclase matrix largely controls the rheology of the analyzed granulite grade mylonites. This result is consistent with studies of naturally deformed, high-grade mafic rocks where plagioclase is often the most easily deformed phase, leading to significant grain size

Table 4. Representative Pyroxene Analyses Used in QUIIF Thermometry Calculations

\begin{tabular}{|c|c|c|c|c|c|c|c|c|c|c|c|c|c|}
\hline $\begin{array}{l}\text { Study Area in } \\
\text { Sample 648-04 }\end{array}$ & $\begin{array}{c}\text { Number of } \\
\text { Analyses }\end{array}$ & $\mathrm{SiO}_{2}$ & $\mathrm{Al}_{2} \mathrm{O}_{3}$ & $\mathrm{TiO}_{2}$ & $\mathrm{Cr}_{2} \mathrm{O}_{3}$ & $\mathrm{MgO}$ & $\mathrm{FeO}$ & $\mathrm{MnO}$ & $\mathrm{CaO}$ & $\mathrm{Na}_{2} \mathrm{O}$ & $\mathrm{K}_{2} \mathrm{O}$ & $\begin{array}{c}\text { Temperature } \\
\left({ }^{\circ} \mathrm{C}\right)\end{array}$ & Error \\
\hline $\begin{array}{l}\text { Clinopyroxene analyses } \\
\text { average area } 3\end{array}$ & $\mathrm{n}=5$ & 52.053 & 1.694 & 0.398 & 0.008 & 14.529 & 8.838 & 0.252 & 20.873 & 0.435 & 0.002 & 862 & \pm 20 \\
\hline $\begin{array}{l}\text { Orthopyroxene neoblast } \\
\text { analyses average area } 3\end{array}$ & $\mathrm{n}=6$ & 53.103 & 0.730 & 0.594 & 0.011 & 23.455 & 20.820 & 0.528 & 0.883 & 0.018 & 0.012 & & \\
\hline $\begin{array}{l}\text { Clinopyroxene analyses } \\
\text { average area } 4\end{array}$ & $\mathrm{n}=21$ & 51.753 & 2.208 & 0.517 & 0.015 & 14.434 & 8.781 & 0.244 & 20.670 & 0.439 & 0.009 & 874 & \pm 14 \\
\hline $\begin{array}{l}\text { Orthopyroxene neoblast } \\
\text { analyses average area } 4\end{array}$ & $\mathrm{n}=15$ & 53.454 & 0.948 & 0.185 & 0.011 & 24.028 & 20.096 & 0.474 & 0.863 & 0.017 & 0.005 & & \\
\hline $\begin{array}{l}\text { Clinopyroxene analyses } \\
\text { average area } 6\end{array}$ & $\mathrm{n}=16$ & 51.587 & 2.318 & 0.503 & 0.015 & 14.375 & 8.811 & 0.268 & 20.538 & 0.450 & 0.009 & 910 & \pm 20 \\
\hline $\begin{array}{l}\text { Orthopyroxene neoblast } \\
\text { analyses average area } 6\end{array}$ & $\mathrm{n}=9$ & 53.032 & 1.183 & 0.185 & 0.015 & 23.634 & 20.228 & 0.495 & 1.032 & 0.020 & 0.004 & & \\
\hline $\begin{array}{l}\text { Clinopyroxene analyses } \\
\text { average area } 7\end{array}$ & $\mathrm{n}=1$ & 52.318 & 1.630 & 0.341 & 0.000 & 14.680 & 9.094 & 0.241 & 21.084 & 0.390 & 0.017 & 885 & \pm 20 \\
\hline $\begin{array}{l}\text { Orthopyroxene neoblast } \\
\text { analyses average area } 7\end{array}$ & $\mathrm{n}=18$ & 53.181 & 1.063 & 0.228 & 0.010 & 23.781 & 20.197 & 0.490 & 0.939 & 0.017 & 0.010 & & \\
\hline
\end{tabular}




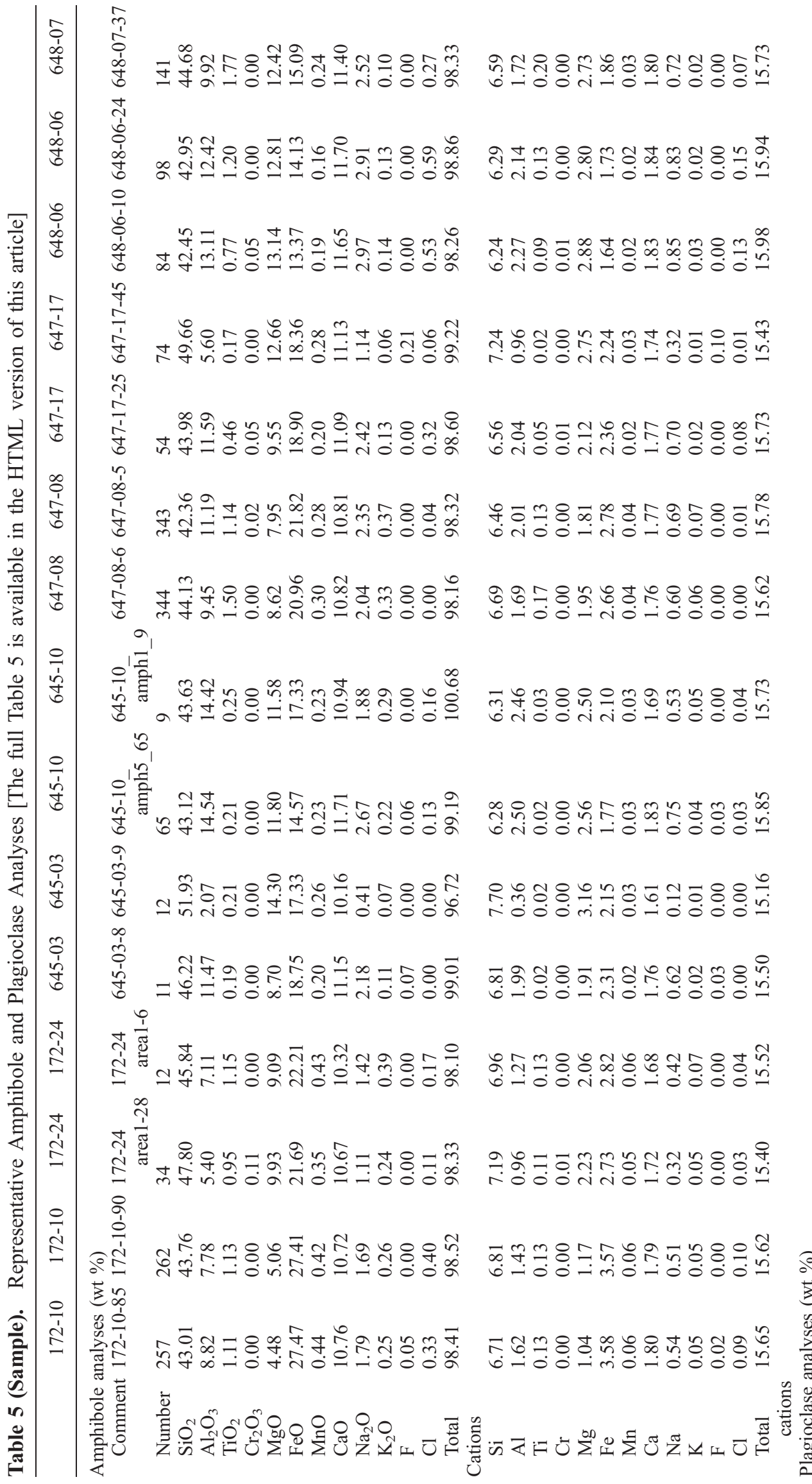

角

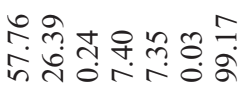

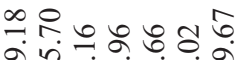

में

ํำ느능

的

กิ๋

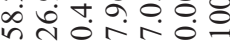

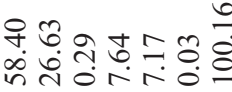

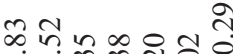

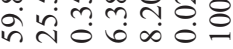

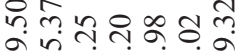

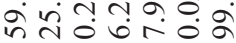

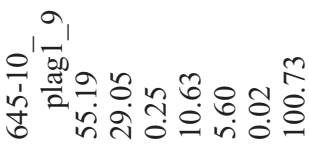
ช

일

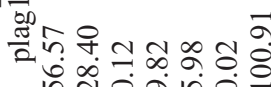

is

ले 하웡ㅇㅇㅇ

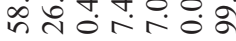

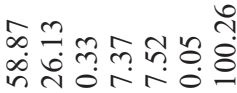

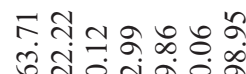

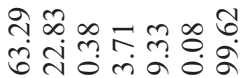

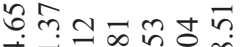

सेतें

$3 n$

๙ิ

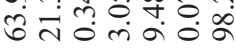

总

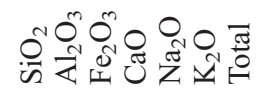




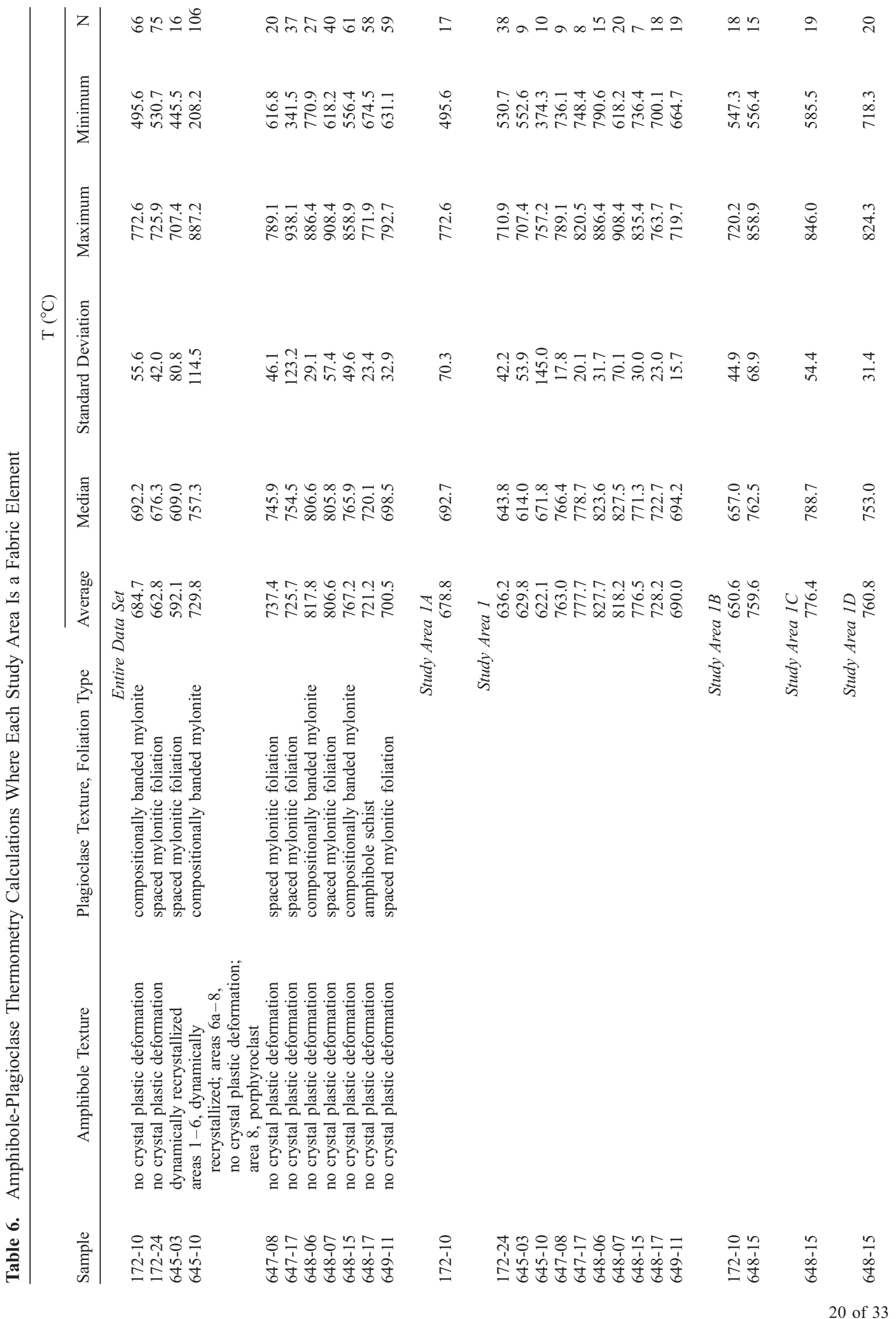




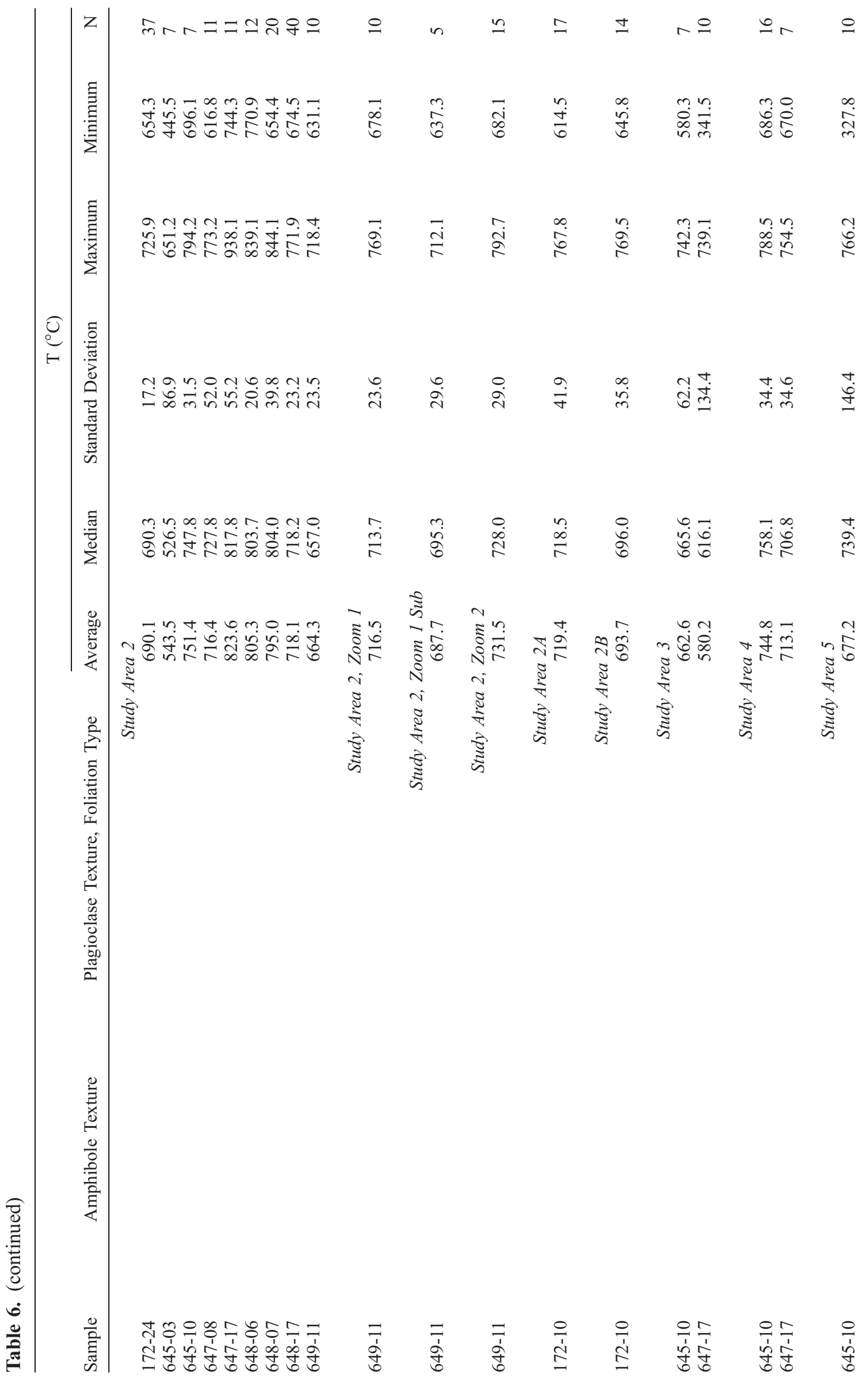


reduction during dynamic recrystallization, implying a relatively weak rheology [Brodie and Rutter, 1985; Rutter, 1999]. Further, the presence of recrystallized anhydrous phases (pyroxene, olivine, and plagioclase) suggests a dry rheology for our samples, and that "dry" experimental flow laws for either plagioclase aggregates $\left(<0.005 \% \mathrm{H}_{2} \mathrm{O}\right)$ or two-phase anorthite-diopside aggregates $(\sim 0.004 \%$ $\mathrm{H}_{2} \mathrm{O}$ ) [e.g., Rybacki and Dresen, 2004; Dimanov and Dresen, 2005; Dimanov et al., 2007] may be representative of lower crustal deformation at Atlantis Bank for granulite grade temperatures, consistent with recent studies of Atlantis Bank granulite grade mylonites [Mehl and Hirth, 2008].

[37] Based on observations of amphibole-filled fractures in granulite grade mylonites, fracture formation and hydrous fluid infiltration began at the transition from granulite to amphibolite grade temperatures $\left(\sim 800^{\circ} \mathrm{C}\right)$ and continued through amphibolite grade temperatures $\left(\sim 820-600^{\circ} \mathrm{C}\right)$, leading to a shift from plagioclase- to amphiboleaccommodated strain localization with decreasing temperature. This was accomplished by the growth of hydrous amphibole at the expense of pyroxene followed by plagioclase, resulting in the modal reduction of the granulite grade rheology-controlling phase, and the increased modal abundance of amphibole. As water has a known weakening effect in shear zones [Tullis et al., 1996], we infer that the infiltration of hydrous fluids at temperatures near the granulite to amphibolite grade transition promoted strain localization at temperatures $<800^{\circ} \mathrm{C}$ by first enhancing dynamic recrystallization of plagioclase and then its subsequent reaction to hydrous amphibole. This led to a shift from largely crystal plastic to semibrittle deformation mechanisms in plagioclase and amphibole.

[38] The addition of hydrous fluids during upper amphibolite grade deformation first promotes replacement of pyroxene by secondary amphibole. Pyroxene porphyroclasts mantled by brown amphibole indicate increasingly hydrous conditions during upper amphibolite mylonitic fabric development. We find that the proportion of amphibole to plagioclase in upper amphibolite mylonites is largely similar to the proportion of pyroxene to plagioclase in granulite grade mylonites; these ratios suggest a direct replacement of pyroxene by amphibole. In lower amphibolite grade rocks, the ratio of amphibole to plagioclase exceeds the ratio of pyroxene to plagioclase in granulite or upper amphibolite grade rocks. With decreasing temperature at amphibolite grade conditions, the 

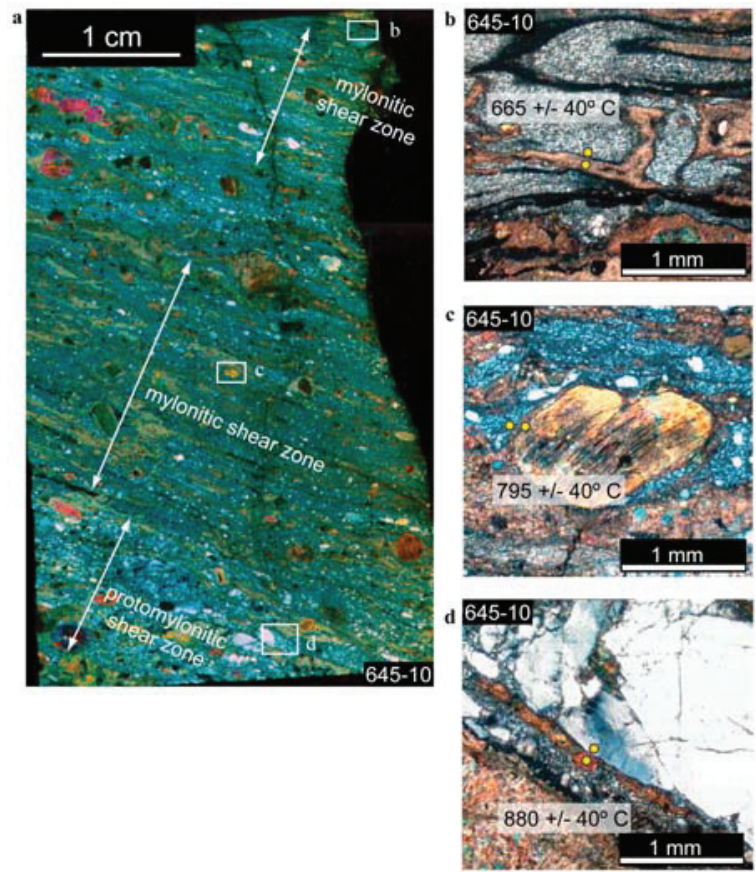

Figure 15. Regions of amphibole-plagioclase thermometry analyses in sample 645-10. (a) Cross-polarized image of the sample thin section. Regions of thermometry analyses are outlined with white boxes. (b) Finegrained region of amphibole and plagioclase analyses (two yellow dots). In this region, $\mathrm{n}=20$. (c) Additional region of amphibole and plagioclase analyses, $\mathrm{n}=20$. (d) Coarse-grained region of amphibole and plagioclase analyses, $\mathrm{n}=20$.

modal proportion of plagioclase decreases while the modal abundance of amphibole increases, suggesting that amphibole grows at the expense of both pyroxene and plagioclase (Tables 1 and 2).
[39] The growth of abundant amphibole in the mylonites requires an influx of hydrous fluids channeled into the shear zones, as well as a mechanism to keep fluid supplied to the shear zone for the duration of amphibolite grade fabric development. The presence of fractures that are either partially healed by bulging dynamic recrystallization of plagioclase at upper amphibolite grade temperatures, and those that are partially or fully healed by growth of secondary amphibole grains at lower amphibolite grade temperatures suggests that the fractures are synkinematic with respect to mylonitic fabric development, and were continuously generated and healed during progressive, down-temperature amphibolite grade deformation [e.g., McCaig and Knipe, 1990; Knipe and McCaig, 1994]. The dynamic process of synkinematic fracture generation, fluid infiltration, and subsequent healing is therefore a viable mechanism for supplying fluids to the detachment fault shear zone.

[40] The change in foliation geometry from compositional to spaced to schistose is largely the result of increased, down-temperature growth of amphibole. In samples with foliation, growth of amphibole around domains of dynamically recrystallized plagioclase suggests that hydrous fluids wetted grain boundaries between recrystallized plagioclase grains, resulting in disruption of the interconnected plagioclase grain networks that effectively localize strain at higher temperatures. Taken with the decrease in modal plagioclase and progressively lower temperatures, the anastomosing amphibole network reduces the influence of plagioclase rhe-
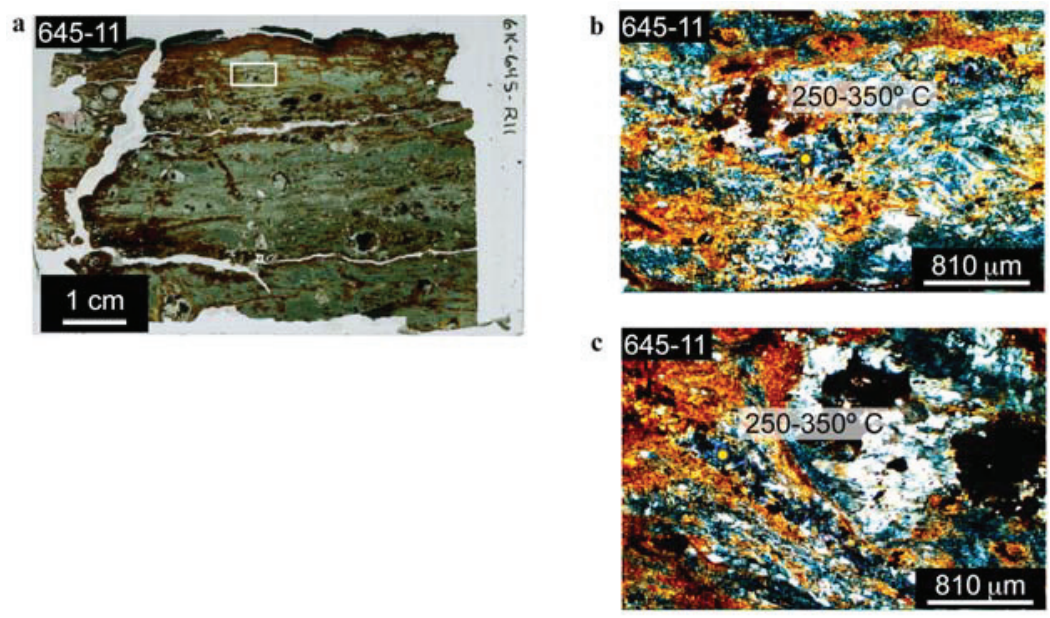

Figure 16. Regions of chlorite thermometry analyses in sample 645-11, collected directly from the detachment fault surface on the seafloor. (a) Plane light image of sample 645-11. The box encloses the region of both sets of chlorite microprobe analyses. (b) Cross-polarized image of one region of chlorite analyses $(n=50)$. (c) Cross-polarized image of the other region of chlorite analyses $(n=50)$. 
Table 7. Representative Chlorite Analyses

\begin{tabular}{|c|c|c|c|c|c|c|c|c|}
\hline & $645-11-50$ & $645-11-2$ & $645-11-38$ & $645-11-82$ & $653-16-2-47$ & $653-16-2-73$ & $653-16-2-37$ & $653-16-2-14$ \\
\hline \multicolumn{9}{|l|}{ Weight percent } \\
\hline $\mathrm{SiO}_{2}$ & 26.76 & 26.52 & 25.77 & 26.74 & 31.19 & 29.92 & 32.42 & 38.09 \\
\hline $\mathrm{Al}_{2} \mathrm{O}_{3}$ & 19.53 & 20.44 & 20.51 & 18.78 & 17.08 & 17.75 & 14.12 & 13.39 \\
\hline $\mathrm{TiO}_{2}$ & 0.04 & 0.03 & 0.22 & 0.03 & 0.06 & 0.02 & 0.06 & 0.09 \\
\hline $\mathrm{MgO}$ & 15.96 & 14.73 & 14.70 & 12.82 & 24.21 & 22.62 & 24.10 & 19.08 \\
\hline $\mathrm{FeO}$ & 26.19 & 26.95 & 27.34 & 29.03 & 14.51 & 16.64 & 15.06 & 15.48 \\
\hline $\mathrm{MnO}$ & 0.13 & 0.15 & 0.09 & 0.14 & 0.06 & 0.18 & 0.13 & 0.16 \\
\hline $\mathrm{Cr}_{2} \mathrm{O}_{3}$ & 0.00 & 0.00 & 0.00 & 0.03 & 0.20 & 0.10 & 0.19 & 0.04 \\
\hline Total & 88.60 & 88.83 & 88.64 & 87.56 & 87.31 & 87.23 & 86.06 & 86.33 \\
\hline \multicolumn{9}{|l|}{ Cation } \\
\hline $\mathrm{Si}$ & 2.80 & 2.77 & 2.71 & 2.87 & 3.09 & 3.01 & 3.27 & 3.77 \\
\hline Al (total) & 2.41 & 2.52 & 2.54 & 2.38 & 2.00 & 2.10 & 1.68 & 1.56 \\
\hline $\mathrm{Ti}$ & 0.00 & 0.00 & 0.02 & 0.00 & 0.00 & 0.00 & 0.00 & 0.01 \\
\hline $\mathrm{Mg}$ & 2.49 & 2.30 & 2.31 & 2.05 & 3.58 & 3.39 & 3.63 & 2.81 \\
\hline $\mathrm{Fe}$ & 2.29 & 2.36 & 2.41 & 2.61 & 1.20 & 1.40 & 1.27 & 1.28 \\
\hline $\mathrm{Mn}$ & 0.01 & 0.01 & 0.01 & 0.01 & 0.00 & 0.02 & 0.01 & 0.01 \\
\hline $\mathrm{Cr}$ & 0.00 & 0.00 & 0.00 & 0.00 & 0.02 & 0.01 & 0.02 & 0.00 \\
\hline Total & 10.00 & 9.96 & 10.00 & 9.93 & 9.90 & 9.93 & 9.88 & 9.44 \\
\hline Temperature $\left({ }^{\circ} \mathrm{C}\right)$ & 330 & 338 & 358 & 308 & 287 & 296 & 242 & 365 \\
\hline
\end{tabular}

ology on the localization of strain by isolating plagioclase, and pinning individual plagioclase grain boundaries, preventing regime 1 grain boundary migration recrystallization, and further crystal plastic deformation of plagioclase. In schistose samples, the near-absence of plagioclase, the absence of evidence for crystal plasticity in amphibole, and the strongly oriented, foliation-defining amphibole grains together are consistent with microstructural evidence for dissolution-precipitation creep processes in amphibole. Similar microstructures have been observed in amphibole in both experimentally and naturally deformed samples, and they have been used to demonstrate that an amphibole lattice preferred orientation can develop without the operation of crystal plastic processes during reaction-controlled dissolution-precipitation creep [Bons and den Brok, 2000; Imon et al., 2004; Díaz Aspiroz et al., 2007; Miranda, 2006]. The evolution in foliation geometry during amphibolite grade deformation suggests a transition from dynamic recrystallization-accommodated strain localization in plagioclase to dissolution-precipitation creep processes in amphibole. Further, these results imply a wet rheology for our samples at upper amphibolite grade temperatures where plagioclase still deforms under dislocation creep, and that "wet" $\left(\geq 0.07 \% \mathrm{H}_{2} \mathrm{O}\right)$ experimental flow laws for plagioclase aggregates [e.g., Dimanov et al., 1999; Rybacki and Dresen, 2000; Offerhaus et al., 2001; Rybacki and Dresen, 2004; Rybacki et al., 2006] may be more representative of lower crustal deformation at Atlantis Bank at these temperatures, consistent with other studies of amphibolite grade mylonites from Atlantis Bank [Miranda, 2006].

[41] At greenschist grade conditions, the proportion of plagioclase in recovered fault rocks is further diminished; with the addition of $\mathrm{Mg}$-rich fluid, reaction of plagioclase to chlorite contributes to the formation of well-foliated, fine-grained chlorite-rich fault schists. There is little evidence of crystal plastic deformation of amphibole or chlorite in the schists, despite well-developed foliation. Our thermometry shows that chlorite growth occurs at lower temperatures than amphibole growth, and we interpret this as evidence that chlorite dissolutionprecipitation creep occurs after amphibole-accommodated dissolution-precipitation creep. Both brown and green amphibole-filled fractures in lower amphibolite grade rocks, and chlorite- and prehnite-filled fractures in greenschist grade rocks demonstrate that synkinematic fracture development and fluid infiltration continued with decreasing temperature. Strain localization along the detachment fault at lower amphibolite and greenschist temperatures is achieved by dissolution-precipitation creep growth of amphibole and chlorite parallel to foliation in the presence of hydrous fluids.

[42] Below greenschist grade conditions, brittle deformation dominates strain localization. Breccias from the detachment surface are dominated by clasts of amphibole and chlorite schist; they rarely contain clasts of gabbro mylonite, oxide gabbro mylonite, and undeformed diabase. Most of the breccia clasts are therefore derived from rocks deformed within the ductile and semibrittle 


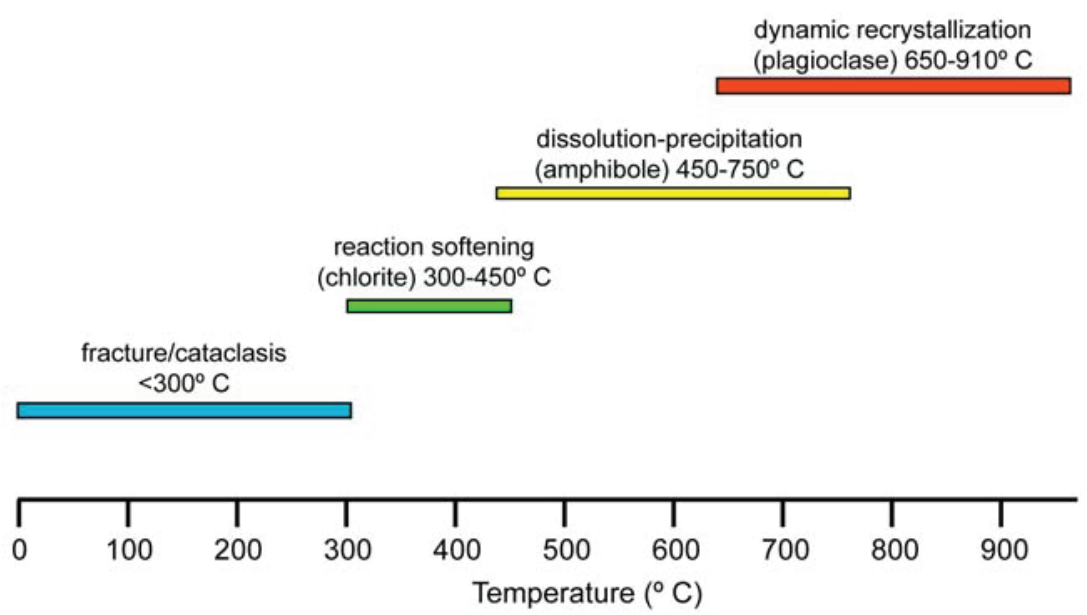

Figure 17. Schematic diagram highlighting the temperature ranges for the deformation mechanisms that promoted strain localization along the Atlantis Bank detachment fault.

regimes. Mylonitic and schistose textures in the clasts indicate semibrittle and ductile deformation occurred at temperatures from $\sim 600$ to $\sim 850^{\circ} \mathrm{C}$. Subgreenschist grade brecciation overprints the higher-temperature ductile and semibrittle deformation, with matrix chlorite growth in fault breccias at temperatures between $\sim 250-350^{\circ} \mathrm{C}$. Either brecciation initiated at temperatures above or similar to this temperature range in order for chlorite to grow in the matrix, or chlorite growth resulted from circulation of fluids after the brecciation was complete.

[43] Down-temperature strain localization within the ductile, semibrittle, and brittle regimes associated with initiation and slip on the detachment fault system at Atlantis Bank is summarized as follows (Figure 17): (1) At granulite grade conditions $\left(\sim 910-862^{\circ} \mathrm{C}\right)$, dynamic recrystallization of plagioclase dominates the initial localization of strain. (2) At amphibolite grade conditions, strain is accommodated by both dynamic recrystallization of plagioclase and dissolution-precipitation creep of amphibole at temperatures $\sim 820-600^{\circ} \mathrm{C}$. (3) At greenschist grade conditions $\left(\sim 450-300^{\circ} \mathrm{C}\right)$, strain is localized by reaction softening due to growth of chlorite. (4) At subgreenschist grade conditions $\left(<300^{\circ} \mathrm{C}\right)$, strain is localized by brittle fracturing and cataclasis.

\section{Distribution of Deformation Fabrics}

\subsection{Variations of Fabric Intensity With Rock Type}

[44] Though we document the onset of strain localization at near-solidus granulite grade temper- atures with development of mylonitic fabrics through amphibolite grade temperatures, the prevalence of crystal plastic fabrics in a range of gabbroic compositions suggests composition-influenced strain localization. We classify the in situ samples as either nonoxide gabbro or oxide gabbro $(>0.5 \%$ oxide) in order to compare fabric intensity with rock type. We designate gabbro, olivine gabbro, and gabbronorite as "nonoxide gabbro," and classify oxide gabbro, oxide olivine gabbro, and olivine oxide gabbro as "oxide gabbro." The highest intensity of crystal plastic fabric development is observed in both nonoxide gabbro and oxide gabbro rock types (Figure 18). Crystal plastic fabric intensity does not appear to correlate with primary rock composition, or structural depth beneath the most recent slip surface. Based on the samples investigated, strain is not preferentially localized in either nonoxide gabbro or oxide gabbro rock compositions.

\subsection{Variations of Fabric Intensity With Structural Depth}

[45] We estimated the structural depth of each sample beneath the detachment fault surface to compare the thickness of ductile, semibrittle and brittle deformation zones across the dissected dome of Atlantis Bank. Due to truncation and displacement of the detachment surface by several transform- and ridge-parallel normal faults (Figure 2), sample depth (collected by submersible) cannot be equated directly with true structural depth beneath the detachment fault surface. We used bathymetric maps, dive sample location projections into "dive profiles," or vertical slices through the bathymetry, and submersible observations to identify exposures 


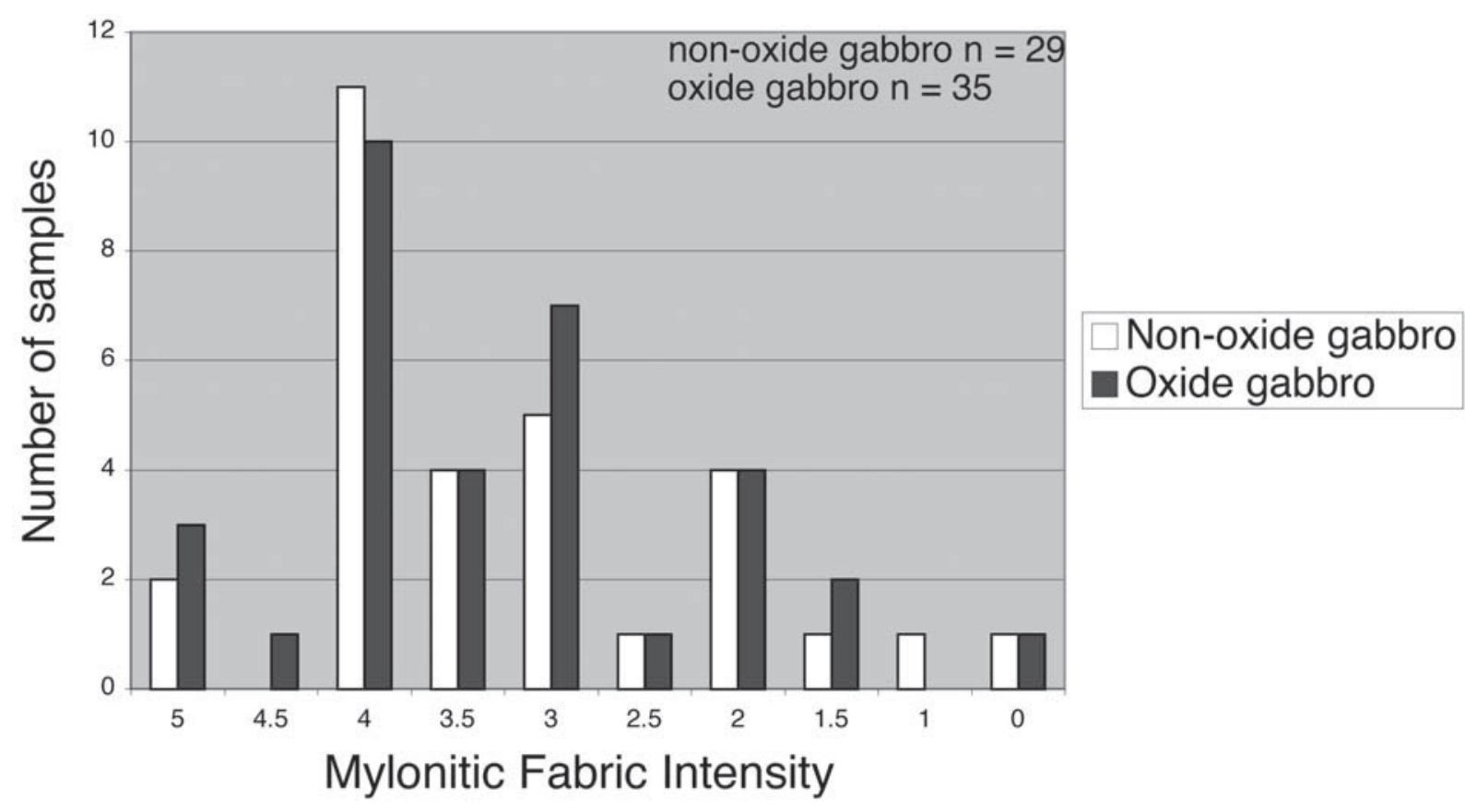

Figure 18. Plot of mylonitic fabric intensity versus rock composition. The nonoxide gabbro and oxide gabbro suites show similar intensities of fabric development, suggesting that strain is not localized preferentially into a particular gabbro composition.

of the relict detachment fault surface. The estimated structural depth of each sample beneath the detachment fault was made by measuring the orthogonal distance between this contoured surface and the sample [e.g., Schroeder and John, 2004]. The dive profiles and accompanying structural depth calculations are shown in the auxiliary material.

[46] Footwall rocks exhibit crystal plastic fabrics distributed over a structural thickness up to $400 \mathrm{~m}$ below the denuded fault surface exposed at the seafloor, and concentrated within the upper $120 \mathrm{~m}$ of this zone. Crystal plastic fabrics vary in intensity with depth, demonstrating localization of ductile deformation into anastomosing shear zones up to tens of meters thick (Figure 19). The presence of high-strain (fabric intensity $>4$ ) fabrics in granulite and upper amphibolite grade rocks shows that strain localization did occur, and was accommodated by dynamic recrystallization of plagioclase within the ductile regime. However, not every granulite grade and upper amphibolite grade shear zone is overprinted by successively down-temperature deformation. Some granulite grade mylonites exhibit only high-temperature assemblages, preserving microstructures indicative of dynamic recrystallization in pyroxene, olivine, and plagioclase. Similarly, some amphibolite grade mylonites exhibit only granulite and amphibolite grade assemb- lages and microstructural evidence of dynamic recrystallization of pyroxene, brown amphibole, and plagioclase. These observations suggest that strain was localized on a few of the high-temperature shear zones with decreasing temperature, such that many shear zones were left with microstructures developed during high-temperature deformation, and not subsequently deformed.

[47] Semibrittle fabrics are also distributed over a structural thickness up to $400 \mathrm{~m}$ beneath the fault, but concentrated in the upper $80 \mathrm{~m}$ of this zone (Figure 19). The greatest intensity of semibrittle fabric development occurs in amphibole schists and amphibole-chlorite schists; these rocks crop out in a zone up to $\sim 20 \mathrm{~m}$ thick directly beneath the detachment fault slip surface (Table 1). Based on textures observed in this study, growth of amphibole in the presence of hydrous fluids lead to the development of amphibole schists. As the schists must preferentially develop in a region of high fluid flow, the incipient detachment fault zone likely was the conduit for the fluids, as fluid flow can be enhanced through fracturing and increased porosity associated with faulting. This is corroborated by the restricted occurrence of amphibole and chlorite schists immediately below (within a few tens of meters) the detachment surface. Similarly, amphibole, chlorite, and talc schists have been identified along and immediately below detach- 


\section{Gabbro Strain Intensity with Structural Depth}

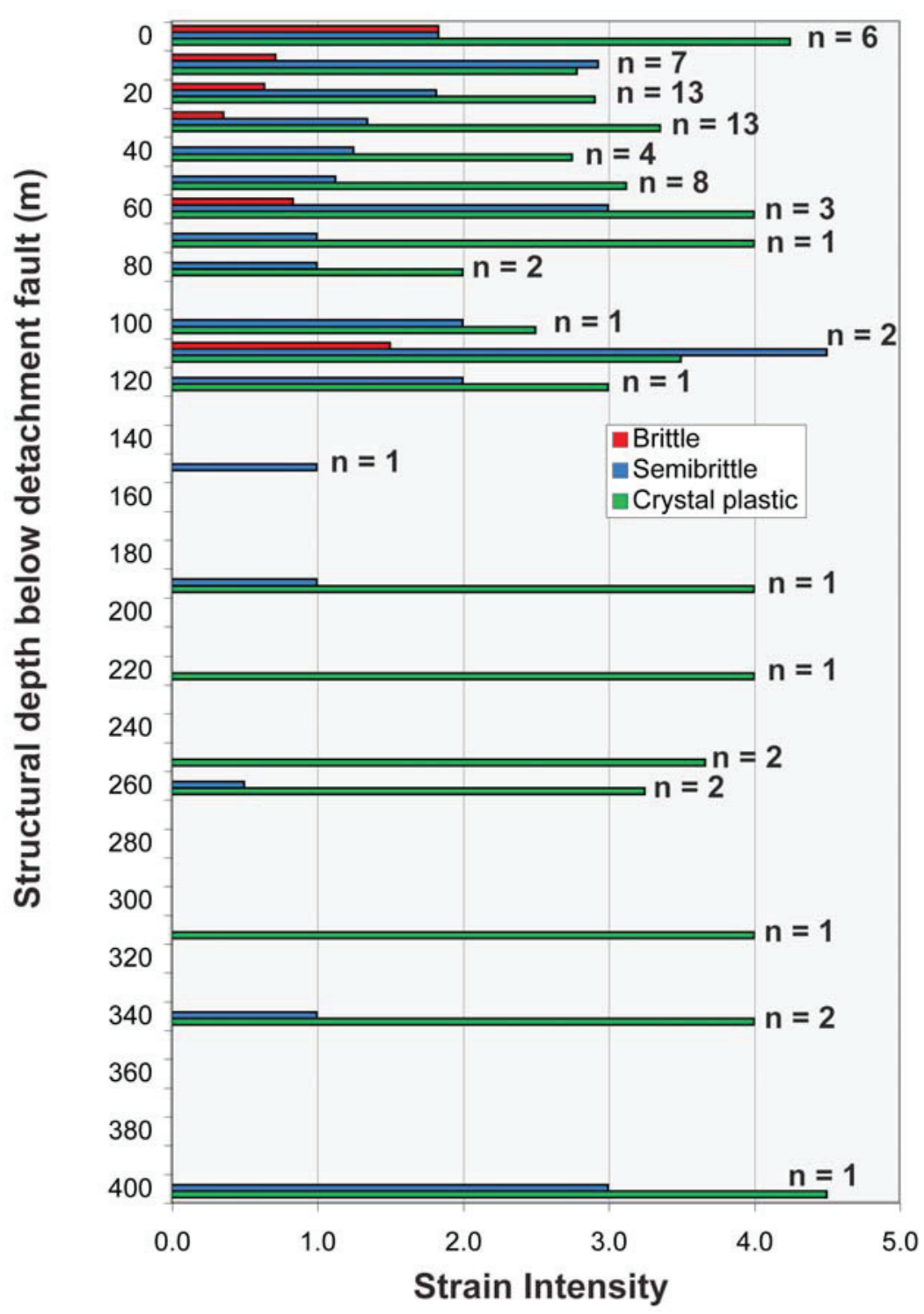

Figure 19. Plot of average strain intensity with structural depth where $\mathrm{n}=$ number of samples within a given $10 \mathrm{~m}$ bin of structural depth. Brittle, semibrittle, and crystal plastic strain intensities are shown as red, blue, and green bars, respectively. Average strain intensity is calculated by the sum of the strain intensities in a given $10 \mathrm{~m}$ bin divided by the number of samples in the bin. Ductile deformation is distributed over the $400 \mathrm{~m}$ thickness of the shear zone at higher strain intensities than either semibrittle or brittle deformation and is concentrated in the upper $120 \mathrm{~m}$ of the detachment fault shear zone. Semibrittle deformation is distributed over the $400 \mathrm{~m}$ thick zone beneath the detachment fault but concentrated in the upper $80 \mathrm{~m}$. Brittle deformation is distributed over the upper $110 \mathrm{~m}$ of the $400 \mathrm{~m}$ thick zone beneath the detachment fault but concentrated in the upper $\sim 30 \mathrm{~m}$.

ment fault surfaces along the Mid-Atlantic Ridge [MacLeod et al., 2002; Escartin et al., 2003; Schroeder and John, 2004; Blackman et al., 2006; Boschi et al., 2006; McCaig et al., 2007].

[48] The greatest magnitudes of brittle fabric intensity occur in fault breccias, locally exposed at the seafloor associated with the principal slip surface. These exposures are characterized by fault breccias that contain clasts of amphibole and chlorite schists, gabbro mylonites, oxide gabbro mylonites and diabase. The restricted occurrence of fault breccias along the detachment surface indicates that the zone of brittle deformation is not appreciable $(<30 \mathrm{~m})$, or may have been eroded 


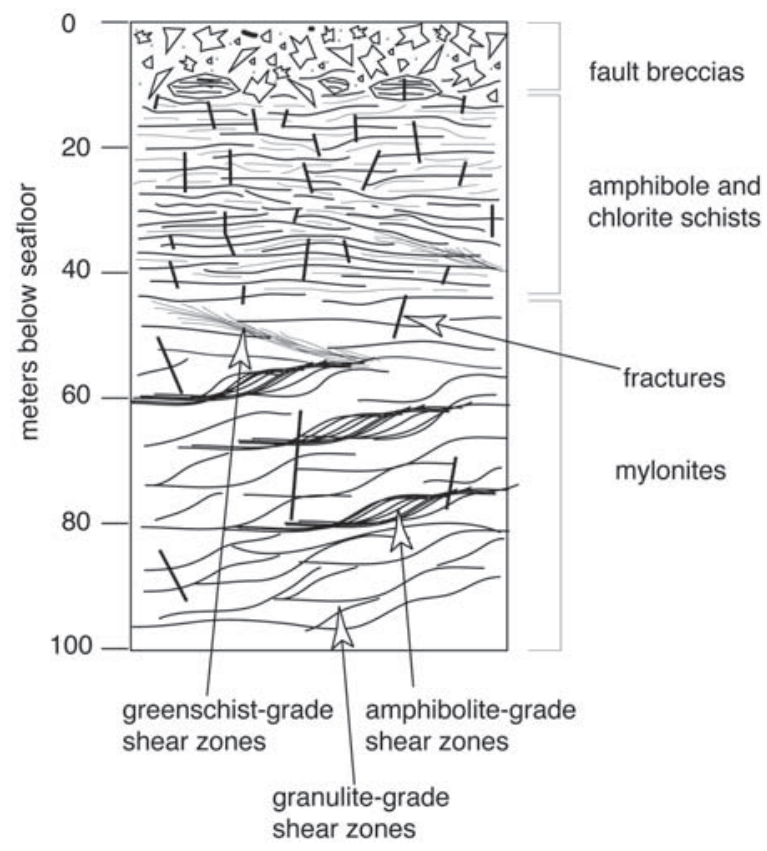

Figure 20. Schematic section through the upper $100 \mathrm{~m}$ of the detachment fault shear zone. The upper portion of the shear zone comprises high-temperature mylonitic shear zones overprinted by amphibole and chlorite schists; both of these rock types are incorporated into fault breccias immediately below the detachment fault slip surface.

during probable subaerial exposure of the fault surface [Shipboard Scientific Party, 1999b]. The clasts contain fabrics indicative of high-temperature deformation in the ductile and semibrittle regimes. The overprinting of high-temperature fabrics by progressively lower-temperature brittle fabrics along the detachment fault, and the structural juxtaposition of brittle rocks above ductile rocks are both traits that are consistent with normal sense motion. These relationships are shown in a schematic diagram for the top $100 \mathrm{~m}$ of the fault system (Figure 20).

\section{Comparison of Strain Localization Processes With Results From ODP Hole 735B}

[49] In ODP Hole 735B, a $~ 100$ m thick mylonitic shear zone is developed in gabbroic rocks at the top of the core, though other mylonitic shear zones are also found downhole (Figure 3) [Cannat, 1991; Cannat et al., 1991; Shipboard Scientific Party, 1999a; Dick et al., 2000; Natland and Dick, 2002]. Granulite grade fabrics in the upper $70 \mathrm{~m}$ of the shear zone are overprinted by amphibolite grade fabrics in the interval $0-30 \mathrm{mbsf}$, and are further overprinted by greenschist grade fabrics in the intervals $\sim 5-10,15-20,45-50$, and $60-70 \mathrm{mbsf}$ [Stakes et al., 1991]. The recovery of fault breccia clasts within the upper $25 \mathrm{~m}$ of the core suggests the presence of a brittle fault zone at the top of Hole 735B. Overprinting fabric relations demonstrate that the shear zone at the top of Hole 735B was progressively overprinted by thinner, lowergrade shear zones, indicating that strain in the main shear zone associated with the detachment fault was localized with decreasing temperature [Dick et al., 1991b; Stakes et al., 1991].

[50] The detachment fault system at Atlantis Bank is suggested to have rooted at a melt-rich zone based on the presence of hypersolidus magmatic fabrics overprinted by subparallel granulite grade crystal plastic fabrics [Cannat, 1991; Cannat et al., 1991; Dick et al., 1991b; Shipboard Scientific Party, 1999b; Dick et al., 2000]. Many zones of crystal plastic deformation coincide with zones of magmatic foliation development, suggesting a continuum between the onset of deformation in the presence of melt and progressive subsolidus deformation [Shipboard Scientific Party, 1999b; Dick et al., 2000]. Of the 4 core complexes sampled by both drill core and submersible, the Atlantis Bank detachment fault system is unique because (1) both ductile and brittle fault rocks are derived from gabbroic rocks and developed during down-temperature deformation from hypersolidus to subgreenschist grade temperatures and (2) there is little evidence for either high- or low-temperature deformation associated with detachment faulting in serpentinized peridotites exposed across $\sim 39 \mathrm{~km}$ parallel to the spreading direction [Arai et al., 2000; Kinoshita et al., 2001; Matsumoto et al., 2002]. The down-temperature rheology of gabbroic rocks is therefore an important influence on the strain localization processes associated with detachment faulting at Atlantis Bank.

[51] Downhole core description from ODP Legs 118, 176 (Hole 735B), and 179 (Hole 1105A) suggest that the main shear zone associated with detachment faulting is $\sim 100 \mathrm{~m}$ thick and that within this zone, the deformation fabric intensity (based primarily on crystal plastic fabric development) increases upward toward the top of Hole $735 \mathrm{~B}$, and toward the detachment fault surface (Figure 3) [Cannat et al., 1991; Shipboard Scientific Party, 1999a; Dick et al., 2000; Casey et al., 2007]. Numerous granulite and amphibolite grade 
crystal plastic shear zones distributed within and below the main shear zone indicate that a thick zone of distributed crystal plastic deformation developed during early, high-temperature detachment faulting [Cannat et al., 1991; Shipboard Scientific Party, 1999b; Dick et al., 2000; Mehl and Hirth, 2008]. An upward increase in the volume percent of amphibole veins has been documented within the upper 200 mbsf of Hole 735B [Dick et al., 1991a]; as intense fracturing and subsequent growth of amphibole are indicative of semibrittle deformation, the upward increase in amphibole content is a manifestation of an upward increase in semibrittle deformation. The low (36\%) core recovery within the upper $25 \mathrm{~m}$ of Hole $735 \mathrm{~B}$ [Cannat et al., 1991] likely reflects the difficulty associated with sampling brittle fault rocks, including incohesive fault breccias from the detachment fault surface exposed at the seafloor. Fragments of brecciated rock were recovered in the core from this interval, indicating that brecciation associated with the main shear zone of the detachment fault (0-100 mbsf) was likely limited to the upper $25 \mathrm{~m}$ of ODP Hole 735B [Shipboard Scientific Party, 1989].

[52] In the submersible samples discussed, a thick zone of ductile deformation associated with detachment faulting is inferred from the depths at which the samples were acquired. While the intensity of ductile fabric development varies irregularly with depth, the intensity of semibrittle and brittle fabric development increases toward the detachment surface. Therefore, the upward increase in deformation intensity toward the detachment fault surface is a pattern common to both drill core and submersible sample sets.

[53] Initiation of detachment faulting at hypersolidus conditions and the tectonic evolution of the detachment fault system through granulite and amphibolite grade conditions as documented in ODP Hole 735B [Cannat et al., 1991; Mehl and Hirth, 2008] and 1105A [Shipboard Scientific Party, 1999a] is largely corroborated by the textures observed in the submersible samples. Mehl and Hirth [2008] show that granulite grade deformation in ODP Hole 735B occurred at temperatures ranging from $808 \pm 14^{\circ} \mathrm{C}$ to $946 \pm 69^{\circ} \mathrm{C}$; our granulite grade thermometry calculations for the submersible samples $\left(862 \pm 20^{\circ} \mathrm{C}\right.$ to $\left.910 \pm 20^{\circ} \mathrm{C}\right)$ are within this range. Though there is evidence for early, high-temperature dynamic recrystallization of plagioclase leading to strain localization at granulite and amphibolite grade temperatures, strain does not appear to be preferentially localized into oxide-rich gabbros at granulite grade and lower temperatures in the submersible samples. In Figure 19, high $(>4)$ ductile fabric intensity values are associated with olivine gabbro mylonites, gabbro mylonites and oxide gabbro mylonites. Further, not all oxide gabbros have fabric intensity values $>4$. In addition, oxide gabbro mylonites with highintensity ductile fabric development do not exhibit the complete down-temperature spectrum (from granulite grade temperatures through subgreenschist grade temperatures) of overprinting relationships. Oxide gabbros do not develop deformation textures below amphibolite grade temperatures, suggesting that strain is localized into nonoxide gabbros below temperatures of $\sim 450^{\circ} \mathrm{C}$ (Table 1). Amphibole schists rarely contain abundant oxide, and fault breccias contain very few clasts of oxide gabbro mylonite, both suggesting that oxide gabbros do not strongly influence strain localization processes at lower amphibolite, greenschist, and subgreenschist grade conditions.

[54] Finally, results of this work, taken with recent thermochronologic, rheologic, and geophysical studies from the Atlantis Bank detachment, permit estimation of the duration of detachment faulting, strain rates associated with high-temperature deformation, and detachment fault slip magnitude. Cooling rates over Atlantis Bank are interpreted from both ODP 735B core samples and in situ submersible samples using the Ti-in-zircon crystallization temperature $\left(\sim 850 \pm 50^{\circ} \mathrm{C}\right.$ [Grimes et al., 2007]), the Curie temperature associated with magnetic anomalies $\left(\sim 540^{\circ} \mathrm{C}\right.$ [Baines et al., 2008]), and ${ }^{40} \mathrm{Ar} /{ }^{39} \mathrm{Ar}$ biotite closure temperature $\left(\sim 365^{\circ} \mathrm{C}\right.$ [John et al., 2004]). The range in closure temperatures $\left(\sim 850-365^{\circ} \mathrm{C}\right)$ is similar to the range of deformation temperatures interpreted from mineral thermometry outlined in our study. Geochronologic and thermochronologic ages associated with this temperature range $\left(850-365^{\circ} \mathrm{C}\right)$ indicate rapid cooling $\left(>800^{\circ} \mathrm{C} / \mathrm{myr}\right)$ between $\sim 11.99 \pm 0.05$ Ma [Baines et al., 2009] and $11.46 \pm 0.35 \mathrm{Ma}$ [John et al., 2004]. Based on these results we suggest that strain localized rapidly at granulite to greenschist grade temperatures within $\sim 500 \mathrm{kyr}$ of igneous crystallization, consistent with conductive cooling models at depths ranging from 0 to 1500 mbsf [Schwartz et al., 2009].

[55] Rheologic studies of mylonites from Atlantis Bank also suggest rapid strain localization. Mehl and Hirth [2008] examine granulite grade gabbro mylonites from ODP Hole 735B and document 
dislocation creep and grain boundary sliding accommodated diffusion creep in plagioclase and pyroxene at $\sim 900-850^{\circ} \mathrm{C}$ under strain rates of $10^{-12}$ to $10^{-11} \mathrm{~s}^{-1}$. Miranda [2006] examined amphibolite grade gabbro mylonites from in situ submersible samples, and documents a transition from dislocation creep to diffusion creep in plagioclase at $\sim 750-670^{\circ} \mathrm{C}$ under strain rates of $10^{-12}$ to $10^{-11} \mathrm{~s}^{-1}$. Given that rates of detachment faulting at Atlantis Bank are equivalent to the half-spreading rate between the Antarctic and African plates $(\sim 14+1.8 /-1.5 \mathrm{~km} / \mathrm{Myr})$, and accounted for up to $\sim 80 \%$ of the full plate spreading [Baines et al., 2008], the estimated strain rates at granulite and amphibolite grade temperatures are equivalent to the half-spreading rate accommodated on a $<100 \mathrm{~m}$ wide shear zone, consistent with the observed thickness of the main detachment fault shear zone recovered from ODP Hole 735B [Miranda, 2006]. Using the half-spreading rate outlined above [Baines et al., 2008], the $\sim 500 \mathrm{kyr}$ duration of fabric development corresponds to $\sim 7 \mathrm{~km}$ of slip along the detachment fault at strain rates of at least $10^{-12}$ to $10^{-11} \mathrm{~s}^{-1}$. Assuming an initial fault dip of $50-70^{\circ}$ equivalent to that outlined by deMartin et al. [2007] based on microseismicity for the active TAG detachment fault along the Mid-Atlantic Ridge, we estimate that granulite to greenschist grade deformation and associated strain localization occurred within $\sim 2.5$ to $4.5 \mathrm{~km}$ of the ridge axis. This estimate is within the boundaries of the modern axial valley, interpreted to be $\sim 5-10 \mathrm{~km}$ wide based on bathymetry and magnetic anomalies [Hosford et al., 2003]. The rapid localization of strain implied by combined thermochronology and mineral thermometry suggests that the detachment fault system at Atlantis Bank was initiated and strain was localized over hypersolidus, granulite and greenschist grade temperatures within the confines of the axial valley along the Southwest Indian Ridge in $<500 \mathrm{kyr}$.

\section{Conclusions}

[56] Microstructural observations and mineral thermometry from in situ samples collected from the Atlantis Bank oceanic core complex indicate that detachment faulting was initiated under hypersolidus conditions in the ductile regime, and continued to subgreenschist temperatures through the semibrittle and brittle regimes with progressive strain localization. The down-temperature sequence of fabric development is manifested within dominantly gabbroic rocks, suggesting that the development of the Atlantis Bank detachment fault system cannot be explained by models for detachment faulting that require strain partitioning between crust and mantle rocks [e.g., Escartin et al., 2003; Ildefonse et al., 2007]. Initiation of detachment faulting at hypersolidus conditions and the extensive high-temperature crystal plastic fabric development in gabbroic rocks at near-solidus temperatures demonstrates that the onset of core complex development was coeval with magma crystallization, inconsistent with models that require strain localization dominantly within the brittle regime along a low-temperature alteration front [e.g., Escartin et al., 2003]. Our model for detachment faulting at Atlantis Bank involves reaction-driven changes in gabbro rheology that promote down-temperature changes in deformation mechanisms. A key feature is development of synkinematic fractures as a mechanism for enhancing reaction of both pyroxene and plagioclase. The onset of synkinematic fracturing at $\sim 800^{\circ} \mathrm{C}$ promotes the following sequence of deformation mechanisms that enable strain localization: plagioclase-accommodated dislocation creep at temperatures between 910 and $650^{\circ} \mathrm{C}$, amphiboleaccommodated dissolution-precipitation creep at temperatures $\sim 750-450^{\circ} \mathrm{C}$, chlorite-accommodated reaction softening at temperatures $\sim 450-300^{\circ} \mathrm{C}$, and brittle fracturing and cataclasis at temperatures $<300^{\circ} \mathrm{C}$.

[57] The initiation of detachment faulting at nearsolidus conditions and the tectonic evolution of the detachment fault system through granulite and amphibolite grade conditions as documented in ODP Hole 735B [Cannat et al., 1991] and 1105A [Shipboard Scientific Party, 1999a] is largely corroborated by the textures observed in the submersible samples. In addition, the progressive overprinting of the $100 \mathrm{~m}$ thick main shear zone at the top of ODP Hole 735B by successively thinner and lower-grade shear zones is also similar to the pattern of overprinting relationships observed in the $\sim 120 \mathrm{~m}$ thick main shear zone interpreted from the submersible samples. However, in contrast to the ODP 735B samples, crystal plastic deformation does not appear to be preferentially localized into oxide-rich gabbros at granulite grade and lower temperatures in our sample set. Together, the in situ submersible samples from this study and core from ODP Holes $735 \mathrm{~B}$ and $1105 \mathrm{~A}$ show that there is little evidence for fabric development and strain localization in serpentinized peridotites, demonstrating the lateral continuity of strain localization mechanisms developed within gabbroic rocks ex- 
posed in the footwall over a distance $\sim 39 \mathrm{~km}$ parallel to the spreading direction.

\section{Acknowledgments}

[58] We thank the captain and crew of the Yokosuka, Shinkai 6500, Kairei, and Kaiko and their respective shipboard scientific parties. We thank B. Ron Frost for assistance with petrographic analysis, advice about the QUILF thermometer, and discussions about the relationship between textures and metamorphic reactions; Susan Swapp for assistance with electron microprobe analyses; Graham Baines for the GMT maps of Atlantis Bank (Figures 1 and 2); Henry Dick for the use of samples 172-10 and 172-24; Graham Baines, Mike Cheadle, Greg Hirth, and Joshua J. Schwartz for discussions during the project; and Graham Baines and Joshua J. Schwartz for initial reviews of the manuscript. Funding for this work was provided by a Wyoming NASA space grant and a California State University Northridge probationary faculty grant to E. A. Miranda and NSF OCE grant 0352054 to B. E. John and M.J. Cheadle. We thank Donna Blackman and Andrew McCaig for constructive reviews that helped improve our manuscript.

\section{References}

Andersen, D. J., and D. H. Lindsley (1993), QUILF: A Pascal program to assess equilibria among $\mathrm{Fe}-\mathrm{Mg}-\mathrm{Mn}-\mathrm{Ti}$ oxides, pyroxenes, olivine, and quartz, Comput. Geosci., 19, 1333-1350, doi:10.1016/0098-3004(93)90033-2.

Arai, S., H. J. B. Dick, and the Scientific Party (2000), MODE2000 cruise report, Jpn. Mar. Sci. and Technol. Cent., Yokosuka, Japan.

Baines, A. G., M. J. Cheadle, H. J. B. Dick, A. H. Scheirer, B. E. John, N. J. Kusznir, and T. Matsumoto (2003), Mechanism for generating the anomalous uplift of oceanic core complexes: Atlantis Bank, Southwest Indian Ridge, Geology, 31, 1105-1108, doi:10.1130/G19829.1.

Baines, A. G., M. J. Cheadle, H. J. B. Dick, A. H. Scheirer, B. E. John, N. J. Kusznir, and T. Matsumoto (2007), Evolution of the Southwest Indian Ridge from $55^{\circ} 45^{\prime} \mathrm{E}$ to $62^{\circ} \mathrm{E}$ : Changes in plate-boundary geometry since $26 \mathrm{Ma}$, Geochem. Geophys. Geosyst., 8, Q06022, doi:10.1029/2006GC001559.

Baines, A. G., M. J. Cheadle, B. E. John, and J. J. Schwartz (2008), Rate of detachment faulting at Atlantis Bank, SW Indian Ridge, Earth Planet. Sci. Lett., 273, 105-114, doi:10.1016/j.eps1.2008.06.013.

Baines, A. G., M. J. Cheadle, B. E. John, C. B. Grimes, J. J. Schwartz, and J. L. Wooden (2009), SHRIMP Pb/U zircon ages constrain gabbroic crustal accretion at Atlantis Bank on the ultraslow-spreading Southwest Indian Ridge, Earth Planet. Sci. Lett., 287, 540-550, doi:10.1016/j.epsl.2009.09.002.

Blackman, D. K., J. R. Cann, B. Janssen, and D. K. Smith (1998), Origin of extensional core complexes: Evidence from the Mid-Atlantic Ridge at Atlantis Fracture Zone, J. Geophys. Res., 103, 21,315-21,333, doi:10.1029/ 98JB01756.

Blackman, D. K., et al. (2001), Seafloor mapping and sampling of the MAR 30 degrees $\mathrm{N}$ oceanic core complex-MARVEL (Mid-Atlantic Ridge vents in extending lithosphere) 2000, InterRidge News, 10, 33-36.

Blackman, D. K., et al. (2002), Geology of the Atlantis Massif (Mid-Atlantic Ridge, $30^{\circ} \mathrm{N}$ ): Implications for the evolution of an ultramafic oceanic core complex, Mar. Geophys. Res., 23, 443-469, doi:10.1023/B:MARI.0000018232.14085.75.

Blackman, D. K., B. Ildefonse, B. E. John, Y. Ohara, D. J. Miller, C. J. MacLeod, and Expedition 304/305 Scientists (2006), Proceedings of the Integrated Ocean Drilling Program, vol. 304/305, doi:10.2204/iodp.proc.304305.101, Integrated Ocean Drill. Program, College Station, Tex.

Bons, P. D., and B. den Brok (2000), Crystallographic preferred orientation development by dissolution-precipitation creep, J. Struct. Geol., 22, 1713-1722, doi:10.1016/S01918141(00)00075-4.

Boschi, C., G. L. Früh-Green, A. Delacour, J. A. Karson, and D. S. Kelley (2006), Mass transfer and fluid flow during detachment faulting and development of an oceanic core complex, Atlantis Massif (MAR $\left.30^{\circ} \mathrm{N}\right)$, Geochem. Geophys. Geosyst., 7, Q01004, doi:10.1029/2005GC001074.

Brodie, K. H., and E. H. Rutter (1985), On the relationship between deformation and metamorphism, with special reference to the behavior of basic rocks, in Metamorphic Reactions: Kinetics, Textures, and Deformation, edited by A. B. Thompson and D. C. Rubie, pp. 138-179, Springer, New York.

Cann, J. R., D. K. Blackman, D. K. Smith, E. McAllister, B. Janssen, S. Mello, E. Averinos, A. R. Pascoe, and J. Escartin (1997), Corrugated slip surfaces formed at ridge-transform intersections on the Mid-Atlantic Ridge, Nature, 385, 329332, doi: $10.1038 / 385329 \mathrm{a} 0$.

Cannat, M. (1991), Plastic deformation at an oceanic spreading ridge; a microstructural study of the Site 735 gabbros (southwest Indian Ocean), Proc. Ocean Drill. Program Sci. Results, 118, 399-408.

Cannat, M., C. Mevel, and D. Stakes (1991), Normal ductile shear zones at an oceanic spreading ridge: Tectonic evolution of Site 735B gabbros (southwest Indian Ocean), Proc. Ocean Drill. Program Sci. Results, 118, 415-429.

Cannat, M., G. Ceuleneer, and J. M. Fletcher (1997), Ultramafic and gabbroic exposures at the Mid-Atlantic Ridge: Geological mapping in the $15^{\circ} \mathrm{N}$ region, Tectonophysics, 279, 193-213, doi:10.1016/S0040-1951(97)00113-3.

Casey, J. F., D. Banerji, and P. Zarian (2007), Leg 179 synthesis: Geochemistry, stratigraphy, and structure of gabbroic rocks drilled in ODP Hole 1105A, Southwest Indian Ridge, Proc. Ocean Drill. Program Sci. Results, 179, 1-125, doi:10.2973/odp.proc.sr.179.001.2007.

Cathelineau, M. (1988), Cation site occupancy in chlorites and illites as a function of temperature, Clay Miner, 23, 471485, doi:10.1180/claymin.1988.023.4.13.

Ceuleneer, G., and M. Cannat (1997), High-temperature ductile deformation of Site 920 peridotites, Proc. Ocean Drill. Program Sci. Results, 153, 23-34, doi:10.2973/odp.proc. sr.153.002.1997.

deMartin, B., R. A. Sohn, J. P. Canales, and S. E. Humphris (2007), Kinematics and geometry of active detachment faulting beneath the Trans-Atlantic Geotraverse (TAG) hydrothermal field on the Mid-Atlantic Ridge, Geology, 35, 711-714, doi:10.1130/G23718A.1.

Díaz Aspiroz, M. D., G. E. Lloyd, and C. Fernandez (2007), Development of lattice preferred orientation in clinoamphiboles deformed under low-pressure metamorphic conditions: A SEM/EBSD study of metabasites from the Aracena metamorphic belt (SW Spain), J. Struct. Geol., 29, 629-645, doi:10.1016/j.jsg.2006.10.010.

Dick, H. J. B., P. S. Meyer, S. Bloomer, S. Kirby, D. Stakes, and C. Mawer (1991a), Lithostratigraphic evolution of an insitu section of oceanic layer 3, Proc. Ocean Drill. Program Sci. Results, 118, 439-538. 
Dick, H. J. B., H. Schouten, P. S. Meyer, D. G. Gallo, H. Berge, R. Tyce, P. Patriat, K. T. M. Jonson, J. E. Snow, and A. Fisher (1991b), Tectonic evolution of the Atlantis II fracture zone, Proc. Ocean Drill. Program Sci. Results, 118, 359-398.

Dick, H. J. B., et al. (2000), A long in situ section of the lower ocean crust; results of ODP Leg 176 drilling at the Southwest Indian Ridge, Earth Planet. Sci. Lett., 179, 31-51, doi:10.1016/S0012-821X(00)00102-3.

Dimanov, A., and G. Dresen (2005), Rheology of synthetic anorthite-diopside aggregates: Implications for ductile shear zones, J. Geophys. Res., 110, B07203, doi:10.1029/ 2004JB003431.

Dimanov, A., G. Dresen, X. Xiao, and R. Wirth (1999), Grain boundary diffusion creep of synthetic anorthite aggregates: The effect of water, J. Geophys. Res., 104, 10,483-10,497, doi:10.1029/1998JB900113.

Dimanov, A., E. Rybacki, R. Wirth, and G. Dresen (2007), Creep and strain-dependent microstructures of synthetic anorthite-diopside aggregates, J. Struct. Geol., 29, 1049-1069, doi:10.1016/j.jsg.2007.02.010.

Escartin, J., C. Mevel, C. J. MacLeod, and A. M. McCaig (2003), Constraints on deformation conditions and the origin of oceanic detachments: The Mid-Atlantic Ridge core complex at $15^{\circ} 45^{\prime} \mathrm{N}$, Geochem. Geophys. Geosyst., 4(8), 1067, doi:10.1029/2002GC000472.

Frost, B. R., and D. H. Lindsley (1992), Equilibria among FeTi oxides, pyroxenes, olivine, and quartz: Part II. Application, Am. Mineral., 77, 1004-1020.

Frost, B. R., D. H. Lindsley, and D. J. Andersen (1988), Fe-Ti oxide-silicate equilibria; assemblages with fayalitic olivine, Am. Mineral., 73, 727-740.

Grimes, C. B., B. E. John, P. B. Kelemen, F. Mazdab, J. L. Wooden, M. J. Cheadle, K. Hanghoi, and J. J. Schwartz (2007), The trace element chemistry of zircons from oceanic crust: A method for distinguishing detrital zircon provenance, Geology, 35, 643-646, doi:10.1130/G23603A.1.

Handy, M. R. (1989), Deformation regimes and the rheological evolution of fault zones in the lithosphere: The effects of pressure, temperature, grain size and time, Tectonophysics, 163, 119-152, doi:10.1016/0040-1951(89)90122-4.

Harigane, Y., K. Michibayashi, and Y. Ohara (2008), Shearing within lower crust during progressive retrogression: Structural analysis of gabbroic rocks from the Godzilla Mullion, an oceanic core complex in the Parece Vela backarc basin, Tectonophysics, 457, 183-196, doi:10.1016/j.tecto.2008. 06.009 .

Hirth, G., and J. Tullis (1992), Dislocation creep regimes in quartz aggregates, J. Struct. Geol., 14, 145-159, doi:10.1016/0191-8141(92)90053-Y.

Holland, T., and J. Blundy (1994), Non-ideal interactions in calcic amphiboles and their bearing on amphibole-plagioclase thermometry, Contrib. Mineral. Petrol., 116, 433447, doi:10.1007/BF00310910.

Hosford, A., M. Tivey, T. Matsumoto, H. J. B. Dick, H. Schouten, and H. Kinoshita (2003), Crustal magnetization and accretion at the Southwest Indian Ridge near the Atlantis II fracture zone, 0-25 Ma, J. Geophys. Res., 108(B3), 2169, doi:10.1029/2001JB000604.

Ildefonse, B., D. K. Blackman, B. E. John, Y. Ohara, D. J. Miller, and C. J. MacLeod (2007), Oceanic core complexes and crustal accretion at slow-spreading ridges, Geology, 35, 623-626, doi:10.1130/G23531A.1.

Imon, R., T. Okudaira, and K. Kanagawa (2004), Development of shape- and lattice-preferred orientations of amphibole grains during initial cataclastic deformation and subsequent deformation by dissolution-precipitation creep in amphibolites from the Ryoke metamorphic belt, SW Japan, J. Struct. Geol., 26, 793-805, doi:10.1016/j.jsg.2003.09.004.

John, B. E., D. A. Foster, J. M. Murphy, M. J. Cheadle, A. G. Baines, C. M. Fanning, and P. Copeland (2004), Determining the cooling history of in situ lower oceanic crust-Atlantis Bank, SW Indian Ridge, Earth Planet. Sci. Lett., 222, 145160, doi:10.1016/j.eps1.2004.02.014.

Jordan, P. G. (1987), The deformational behaviour of bimineralic limestone-halite aggregates, Tectonophysics, 135, 185-197, doi:10.1016/0040-1951(87)90160-0.

Jowett, E. C. (1991), Fitting iron and magnesium into the hydrothermal chlorite geothermometer, paper presented at Joint Annual Meeting, Geol. Assoc. of Can., Toronto, Ont., Canada.

Karson, J. A. (1990), Seafloor spreading on the Mid-Atlantic Ridge: Implications for the structures of ophiolites and oceanic lithosphere produced in slow-spreading environments, in Ophiolites and Oceanic Crustal Analogues, Proceedings of the Symposium "Troodos 1987," edited by J. Malpas et al., pp. 125-130, Geol. Surv. Dep., Nicosia, Cyprus.

Karson, J. A. (1999), Geological investigations of a lineated massif at the Kane Transform Fault: Implications for oceanic core complexes, Philos. Trans. R. Soc. London, Ser. A, 357, 713-740, doi:10.1098/rsta.1999.0350.

Karson, J. A., and H. J. B. Dick (1983), Tectonics of ridgetransform intersections at the Kane fracture zone, Mar. Geophys. Res., 101, 22,051-22,069.

Karson, J. A., and R. M. Lawrence (1997a), Tectonic setting of serpentinite exposures on the western median valley wall of the MARK area in the vicinity of Site 920, Proc. Ocean Drill. Program Sci. Results, 153, 5-21, doi:10.2973/ odp.proc.sr.153.001.1997.

Karson, J. A., and R. M. Lawrence (1997b), Tectonic window into gabbroic rocks of the middle oceanic crust in the MARK area near Sites 921-924, Proc. Ocean Drill. Program Sci. Results, 153, 61-76, doi:10.2973/odp.proc.sr.153.005.1997.

Karson, J. A., et al. (1987), Along-axis variations in seafloor spreading in the MARK area, Nature, 328, 681-685, doi: $10.1038 / 328681 \mathrm{a} 0$.

Karson, J. A., G. L. Früh-Green, D. S. Kelley, E. A. Williams, D. R. Yoerger, and M. Jakuba (2006), Detachment shear zone of the Atlantis Massif core complex, Mid-Atlantic Ridge, $30^{\circ} \mathrm{N}$, Geochem. Geophys. Geosyst., 7, Q06016, doi:10.1029/2005GC001109.

Kelemen, P. B., E. Kikawa, D. J. Miller, and the Shipboard Scientific Party (2007), Leg 209 summary: Processes in a 20km-thick conductive boundary layer beneath the Mid-Atlantic Ridge, $14^{\circ}-16^{\circ}$ N, Proc. Ocean Drill. Program Sci. Results, 209, 1-33, doi:10.2973/odp.proc.sr.209.001.2007.

Kinoshita, H., H. J. B. Dick, and Shipboard Scientific Party (2001), MODE '98 Leg 4 cruise report, Jpn. Mar. Sci. and Technol. Cent., Yokosuka, Japan.

Knipe, R. J., and A. M. McCaig (1994), Microstructural and microchemical consequences of fluid flow in deforming rocks, Geol. Soc. Spec. Publ., 78, 99-111, doi:10.1144/ GSL.SP.1994.078.01.09.

Kohn, M. J., and C. J. Northrup (2009), Taking mylonites' temperatures, Geology, 37, 47-50, doi:10.1130/G25081A.1

Lindsley, D. H., and B. R. Frost (1992), Equilibria among Fe-Ti oxides, pyroxenes, olivine, and quartz: Part I. Theory, Am. Mineral., 77, 987-1003.

MacLeod, C. J., et al. (2002), Direct geological evidence for oceanic detachment faulting: The Mid-Atlantic Ridge, $15^{\circ} 45^{\prime} \mathrm{N}$, Geology, 30, 879-882, doi:10.1130/00917613(2002)030<0879:DGEFOD>2.0.CO;2. 
Matsumoto, T., H. J. B. Dick, and Shipboard Scientific Party (2002), Preliminary report (ABCDE) Yokosuka/Shinkai 6500 YK01-14 cruise results, Jpn. Mar. Sci. and Technol. Cent., Yokosuka, Japan.

McCaig, A. M., and R. J. Knipe (1990), Mass-transport mechanisms in deforming rocks: Recognition using microstructural and microchemical criteria, Geology, 18, 824-827, doi:10.1130/0091-7613(1990)018<0824:MTMIDR>2.3. $\mathrm{CO} ; 2$

McCaig, A. M., R. A. Cliff, J. Escartin, A. E. Fallick, and C. J. MacLeod (2007), Oceanic detachment faults focus very large volumes of black smoker fluids, Geology, 35, 935-938, doi:10.1130/G23657A.1.

Mehl, L., and G. Hirth (2008), Plagioclase preferred orientation in layered mylonites: Evaluation of flow laws for the lower crust, J. Geophys. Res., 113, B05202, doi:10.1029/ 2007JB005075.

Mevel, C., M. Cannat, P. Gente, E. Marion, J. M. Auzende, and J. A. Karson (1991), Emplacement of deep crustal and mantle rocks on the west median valley wall of the MARK area (MAR, $\left.23^{\circ} \mathrm{N}\right)$, Tectonophysics, 190, 31-53, doi:10.1016/0040-1951(91)90353-T.

Miranda, E. A. (2006), Structural development of the Atlantis Bank Oceanic Detachment Fault System, Southwest Indian Ridge, Ph.D. dissertation, 443 pp., Univ. of Wyo., Laramie, 7 Dec.

Mutter, J. C., and J. A. Karson (1992), Structural processes at slow-spreading ridges, Science, 257, 627-634, doi:10.1126/ science.257.5070.627.

Natland, J. H., and H. J. B. Dick (2002), Stratigraphy and composition of gabbros drilled in Ocean Drilling Program Hole 735B, Southwest Indian Ridge; a synthesis of geochemical data, Proc. Ocean Drill. Program Sci. Results, 176, 1-69, doi:10.2973/odp.proc.sr.176.002.2002.

Offerhaus, L. J., R. Wirth, and G. Dresen (2001), Hightemperature creep of polycrystalline albite, in Deformation Mechanisms, Rheology and Tectonics, edited by S. de Meer et al., Utrecht Univ., Noordwijkerhout, Netherlands.

Ohara, Y., T. Yoshida, Y. Kato, and S. Kasuga (2001), Giant megamullion in the Parece Vela backarc basin, Mar. Geophys. Res., 22, 47-61, doi:10.1023/A:1004818225642.

Post, A., and J. Tullis (1999), A recrystallized grain size piezometer for experimentally deformed feldspar aggregates, Tectonophysics, 303, 159-173, doi:10.1016/S0040-1951(98)00260-1.

Ranero, C. R., and T. J. Reston (1999), Detachment faulting at ocean core complexes, Geology, 27, 983-986, doi:10.1130/ 0091-7613(1999)027<0983:DFAOCC $>2.3 . C O ; 2$.

Rutter, E. H. (1999), On the relationship between the formation of shear zones and the form of the flow law for rocks undergoing dynamic recrystallization, Tectonophysics, 303, 147-158, doi:10.1016/S0040-1951(98)00261-3.

Rybacki, E., and G. Dresen (2000), Dislocation and diffusion creep of synthetic anorthite aggregates, J. Geophys. Res., 105, 26,017-26,036, doi:10.1029/2000JB900223.

Rybacki, E., and G. Dresen (2004), Deformation mechanism maps for feldspar rocks, Tectonophysics, 382, 173-187, doi:10.1016/j.tecto.2004.01.006.

Rybacki, E., M. Gottschalk, R. Wirth, and G. Dresen (2006), Influence of water fugacity and activation volume on the flow properties of fine-grained anorthite aggregates, $\mathrm{J}$. Geophys. Res., 111, B03203, doi:10.1029/2005JB003663.

Schroeder, T., and B. E. John (2004), Strain localization on an oceanic detachment fault system, Atlantis Massif, $30^{\circ} \mathrm{N}$,
Mid-Atlantic Ridge, Geochem. Geophys. Geosyst., 5, Q11007, doi:10.1029/2004GC000728.

Schwartz, J. J., B. E. John, M. J. Cheadle, E. A. Miranda, C. B. Grimes, J. L. Wooden, and H. J. B. Dick (2005), Dating the growth of oceanic crust at a slow-spreading ridge, Science, 310, 654-657, doi:10.1126/science.1116349.

Schwartz, J. J., B. E. John, M. J. Cheadle, P. W. Reiners, and A. G. Baines (2009), Cooling history of Atlantis Bank oceanic core complex: Evidence for hydrothermal activity $2.6 \mathrm{Ma}$ off axis, Geochem. Geophys. Geosyst., 10, Q08020, doi:10.1029/2009GC002466.

Shipboard Scientific Party (1988), Site 669, Proc. Ocean Drill. Program Initial Rep., 106/109, 163-174, doi:10.2973/ odp.proc.ir.106109.106.1988.

Shipboard Scientific Party (1989), Site 735, Proc. Ocean Drill. Program Initial Rep., 118, 89-222, doi:10.2973/odp.proc.ir.118.107.1989.

Shipboard Scientific Party (1999a), Leg 179 summary, Proc. Ocean Drill. Program Initial Rep., 179, 1-26, doi:10.2973/ odp.proc.ir.179.101.1999.

Shipboard Scientific Party (1999b), Leg 176 summary, Proc. Ocean Drill. Program Initial Rep., 176, 1-70, doi:10.2973/ odp.proc.ir.176.101.1999.

Shipboard Scientific Party (1999c), Site 735, Proc. Ocean Drill. Program Initial Rep., 176, 1-314, doi:10.2973/ odp.proc.ir.176.103.1999.

Shipboard Scientific Party (2004), Site 1275, Proc. Ocean Drill. Program Initial Rep., 209, 1-139, doi:10.2973/ odp.proc.ir.209.101.2004.

Sibson, R. H. (1977), Fault rocks and fault mechanisms, J. Geol. Soc., 133, 191-213, doi:10.1144/gsjgs.133.3.0191.

Smith, D. K., and J. R. Cann (1993), Building the crust at the Mid-Atlantic Ridge, Nature, 365, 707-715, doi:10.1038/ $365707 \mathrm{a} 0$.

Smith, D. K., J. R. Cann, and J. Escartin (2006), Widespread active detachment faulting and core complex formation near $13^{\circ} \mathrm{N}$ on the Mid-Atlantic Ridge, Nature, 442, 440-443, doi:10.1038/nature04950.

Smith, D. K., J. Escartin, H. Schouten, and J. R. Cann (2008), Fault rotation and core complex formation: Significant processes in seafloor formation at slow-spreading mid-ocean ridges (Mid-Atlantic Ridge, $13^{\circ}-15^{\circ} \mathrm{N}$ ), Geochem. Geophys. Geosyst., 9, Q03003, doi:10.1029/2007GC001699.

Spry, A. H. (1969), Metamorphic Textures, 350 pp., Pergamon, Oxford, U. K.

Stakes, D., C. Mevel, M. Cannat, and T. Chaput (1991), Metamorphic stratigraphy of Hole 735B, Proc. Ocean Drill. Program Sci. Results, 118, 153-180.

Tucholke, B. E., and J. Lin (1994), A geological model for the structure of ridge segments in slow spreading ocean crust, J. Geophys. Res., 99, 11,937-11,958, doi:10.1029/ 94JB00338.

Tucholke, B. E., J. Lin, and M. C. Kleinrock (1998), Megamullions and mullion structure defining oceanic metamorphic core complexes on the Mid-Atlantic Ridge, J. Geophys. Res., 103, 9857-9866, doi:10.1029/98JB00167.

Tucholke, B. E., K. Fujioka, T. Ishihara, G. Hirth, and M. Kinoshita (2001), Submersible study of an oceanic megamullion in the central North Atlantic, J. Geophys. Res., 106, 16,145-16,161, doi:10.1029/2001JB000373.

Tullis, J., R. Yund, and J. Farver (1996), Deformationenhanced fluid distribution in feldspar aggregates and implications for ductile shear zones, Geology, 24, 63-66, doi:10.1130/0091-7613(1996)024<0063:DEFDIF >2.3 $\mathrm{CO} ; 2$. 